U.S. Department of the Interior

U.S. Geological Survey

Prepared in cooperation with

Douglas County and

U.S. Forest Service

\title{
Major-Ion, Nutrient, and Trace-Element Concentrations in the Steamboat Creek Basin, Oregon, 1996
}

Water-Resources Investigations Report 98-4105 
Page Intentionally Blank 


\section{U.S. Department of the Interior \\ U.S. Geological Survey}

\section{Major-Ion, Nutrient, and Trace-Element Concentrations in the Steamboat Creek Basin, Oregon, 1996 \\ By Frank A. Rinella}

Water-Resources Investigations Report 98-4105

Prepared in cooperation with

Douglas County and

U.S. Forest Service 


\section{U.S. DEPARTMENT OF THE INTERIOR \\ BRUCE BABBITT, Secretary}

\section{U.S. GEOLOGICAL SURVEY}

Thomas J. Casadevall, Acting Director

The use of firm, trade, and brand names in this report is for identification purposes only and does not constitute endorsement by the U.S. Geological Survey

For additional information write to:

District Chief

U.S. Geological Survey, WRD

10615 S.E. Cherry Blossom Drive

Portland, Oregon 97216

E-mail: info-or@usgs.gov
Copies of this report can be purchased from:

U.S. Geological Survey

Information Services

Box 25286

Federal Center

Denver, CO 80225 


\section{CONTENTS}

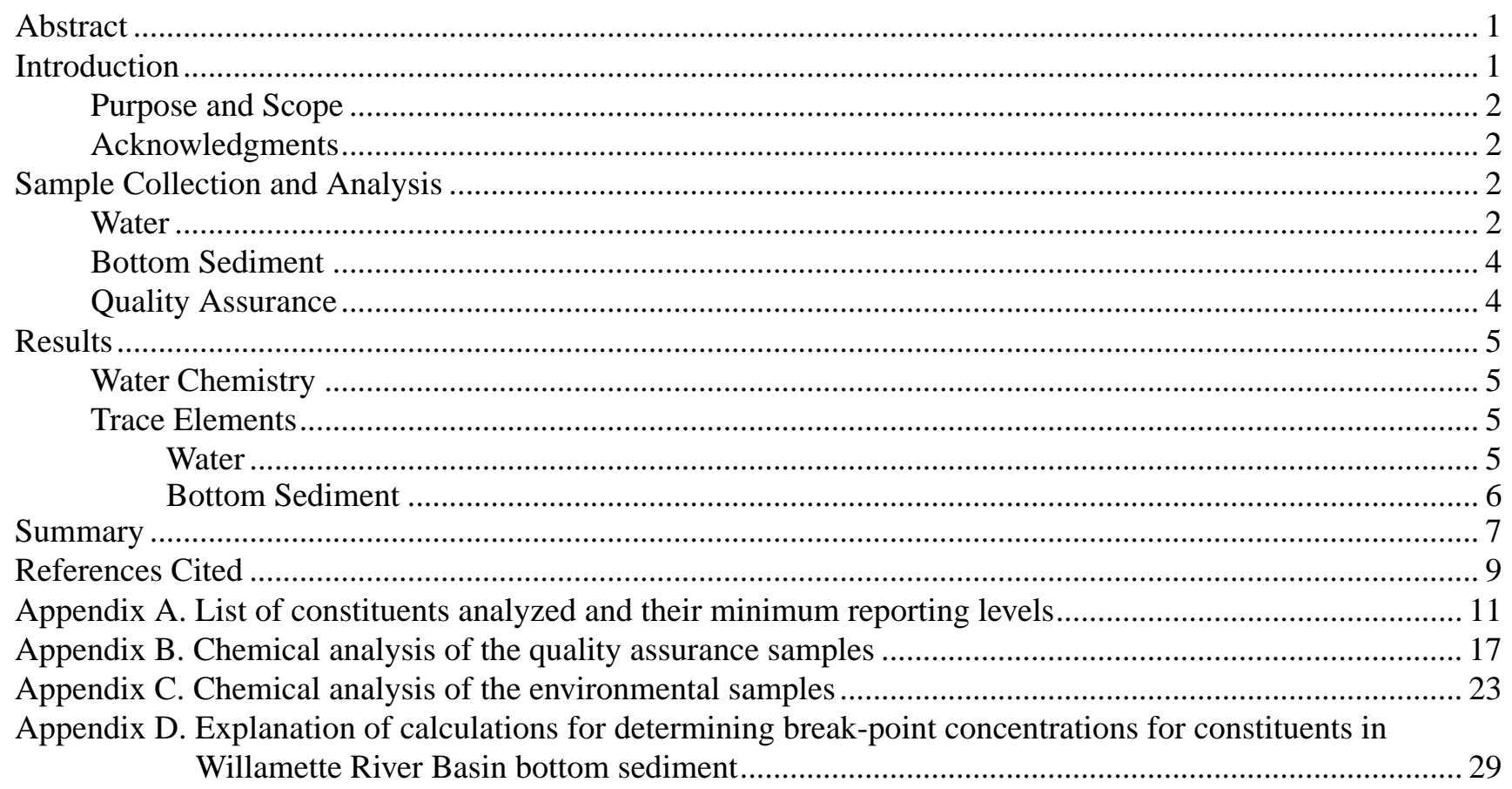

\section{FIGURES}

1. Map showing sampling sites in the Steamboat Creek Basin, Oregon, September 1996 ............................ 3

2. Trilinear diagram of major-ion concentrations in filtered water samples collected from the Steamboat Creek Basin, Oregon, September 9-13, 1996

\section{TABLES}

1. List of sampling sites in the Steamboat Creek Basin, Oregon, September 1996

2. Concentrations of trace elements in filtered water samples collected from the Steamboat Creek Basin, September 9-13, 1996.

3. Concentrations of trace elements in bottom sediment in the Steamboat Creek Basin that either exceeded Willamette River Basin break-point values or Canadian Council of Ministers of the Environment interim threshold effect levels... 
CONVERSION FACTORS

\begin{tabular}{|c|c|c|}
\hline Multiply & By & To obtain \\
\hline \multicolumn{3}{|c|}{ Length } \\
\hline centimeter $(\mathrm{cm})$ & 0.3937 & inch (in) \\
\hline millimeter $(\mathrm{mm})$ & 0.03937 & inch \\
\hline meter $(\mathrm{m})$ & 3.281 & foot $(\mathrm{ft})$ \\
\hline \multicolumn{3}{|c|}{ Volume } \\
\hline milliliter $(\mathrm{mL})$ & 0.001057 & quart (qt) \\
\hline liter $(\mathrm{L})$ & 1.057 & quart \\
\hline \multicolumn{3}{|c|}{ Flow (Volume per unit time) } \\
\hline cubic feet per second $\left(\mathrm{ft}^{3} / \mathrm{s}\right)$ & 0.02832 & cubic meter per second $\left(\mathrm{m}^{3} / \mathrm{s}\right)$ \\
\hline \multicolumn{3}{|c|}{ Concentration in Water } \\
\hline milligrams per liter (mg/L) & 1 & part per million (ppm) \\
\hline micrograms per liter $(\mu \mathrm{g} / \mathrm{L})$ & 1 & parts per billion (ppb) \\
\hline \multicolumn{3}{|c|}{ Concentration in Bottom Sediment } \\
\hline percent & 1 & parts per hundred \\
\hline microgram per gram $(\mu \mathrm{g} / \mathrm{g})$ & 1 & parts per million \\
\hline \multicolumn{3}{|c|}{ Temperature } \\
\hline degrees Celsius $\left({ }^{\circ} \mathrm{C}\right)$ & $\mathrm{F}=1.8\left({ }^{\circ} \mathrm{C}\right)+32$ & degrees Fahrenheit $\left({ }^{\circ} \mathrm{F}\right)$ \\
\hline
\end{tabular}




\title{
Major-Ion, Nutrient, and Trace-Element Concentrations in the Steamboat Creek Basin, Oregon, 1996
}

\author{
By Frank A. Rinella
}

\section{Abstract}

In September 1996, a water-quality study was done by the U.S. Geological Survey, in coordination with the U.S. Forest Service, in headwater streams of Steamboat Creek, a tributary to the North Umpqua River Basin in southwestern Oregon. Field measurements were made in and surface-water and bottomsediment samples were collected from three tributaries of Steamboat Creek-Singe Creek, City Creek, and Horse Heaven Creek-and at one site in Steamboat Creek upstream from where the three tributaries flow into Steamboat Creek.

Water samples collected in Singe Creek had larger concentrations of most major-ion constituents and smaller concentrations of most nutrient constituents than was observed in the other three creeks. City Creek, Horse Heaven Creek, and Steamboat Creek had primarily calcium bicarbonate water, whereas Singe Creek had primarily a calcium sulfate water; the calcium sulfate water detected in Singe Creek, along with the smallest observed alkalinity and $\mathrm{pH}$ values, suggests that Singe Creek may be receiving naturally occurring acidic water.

Of the 18 trace elements analyzed in filtered water samples, only 6 were detected-aluminum, barium, cobalt, iron, manganese, and zinc. All six of the trace elements were detected in Singe Creek, at concentrations generally larger than those observed in the other three creeks. Of the detected trace elements, only iron and zinc have chronic toxicity criteria established by the U.S. Environmental Protection Agency (USEPA) for the protection of aquatic life; none exceeded the USEPA criterion.

Bottom-sediment concentrations of antimony, arsenic, cadmium, copper, lead, mercury, zinc, and organic carbon were largest in City Creek. In City Creek and Horse Heaven Creek, concentrations for 11 constituents-antimony, arsenic, cadmium, copper, lead, manganese (Horse Heaven Creek only), mercury, selenium, silver, zinc, and organic carbon (City Creek only)—exceeded concentrations considered to be enriched in streams of the nearby Willamette River Basin, whereas in Steamboat Creek only two trace elements-antimony and nickel—exceeded Willamette River enriched concentrations. Bottom-sediment concentrations for six of these constituents in City Creek and Horse Heaven Creek-arsenic, cadmium, copper, lead, mercury, and zinc-also exceeded interim Canadian threshold effect level (TEL) concentrations established for the protection of aquatic life, whereas only four constituents between Singe Creek and Steamboat Creek-arsenic, chromium, copper (Singe Creek only), and nickel—exceeded the TEL concentrations.

\section{INTRODUCTION}

The approximately 6,000 acre Bohemia Mining District, which straddles the divide between the Steamboat Creek Subbasin (fig. 1) of the North Umpqua River Basin and the Willamette River Basin to the northwest, was formed in 1867. Since then, hardrock mining, primarily for gold, has been conducted within the watersheds of several small tributaries of Steamboat Creek; these tributaries include City Creek and Horse Heaven Creek (Tim LaMarr, U.S. Forest Service, written commun., 1998). To date, no sampling has been done to characterize major-ion, nutrient, and trace-element concentrations in Steamboat Creek or any of its tributaries.

In 1996, the U.S. Geological Survey (USGS), in cooperation with Douglas County, Oregon, and with the U.S. Forest Service, began a study of the quality of water and bottom sediment in four headwater streams of Steamboat Creek, a tributary to the North Umpqua 
River Basin in southwestern Oregon. The headwaters of two of the tributaries drain the Bohemia Mining District (City Creek and Horse Heaven Creek) and two tributaries are outside of mining activities (Singe Creek and Steamboat Creek).

\section{Purpose and Scope}

This report presents the concentrations of major ions, nutrients, and trace elements in water and bottom sediments collected in the four tributaries during the low-flow conditions of September 9-13, 1996. Stream-water chemistry results are contrasted, and trace-element concentrations compared with U.S. Environmental Protection Agency chronic aquatic life toxicity criteria (U.S. Environmental Protection Agency, 1986). Bottom-sediment trace-element results also are contrasted and compared with concentrations considered to be enriched in streams of the nearby Willamette River Basin and to interim Canadian threshold effect level (TEL) concentrations established for the protection of aquatic life (Environment Canada, 1995).

\section{Acknowledgments}

The author wishes to express special thanks to Mikeal Jones, Steve Hofford, and Larry Broeker from the Supervisor's Office of the Umpqua National Forest, U.S. Forest Service, and to Tim LaMarr from the North Umpqua Ranger District for their assistance and funding of this monitoring effort. Within the U.S. Geological Survey, special thanks also to Mary Janet, who prepared and organized the necessary supplies and equipment for the field effort, and to Chris Brugato, who contributed valuable field assistance.

\section{SAMPLE COLLECTION AND ANALYSIS}

Field measurements and surface-water and bottom-sediment samples at each of the four sites (fig. 1 and table 1) included streamflow, stream temperature, specific conductance, dissolved oxygen, $\mathrm{pH}$, alkalinity, major ions in filtered water (8 constituents), low-level concentrations of nutrients in filtered and unfiltered water ( 8 constituents), low-level concentrations of trace elements in filtered water (18 elements), and trace elements and carbon in bottom sediment ( 47 elements). A list of the chemical constituents analyzed and their minimum reporting levels (MRLs) are given in Appendix A. The MRL is the smallest measured concentration of a constituent that may be reliably reported given the analytical method (Timme, 1995).

\section{Water}

Stream temperature, specific conductance, dissolved oxygen, and $\mathrm{pH}$ were measured using a calibrated Hydrolab multiparameter unit. Because stream widths were less than 8 feet, field measurements were made only near the center of flow at 1 foot or less below water surface. The Hydrolab unit was calibrated at each site before and after sampling. Stream temperatures were recorded to the nearest $0.1^{\circ} \mathrm{C}$ (degree Celsius); specific conductance to the nearest $1 \mu \mathrm{S} / \mathrm{cm}$ (microsiemen per centimeter) at $25^{\circ} \mathrm{C}$; dissolved oxygen to the nearest $0.1 \mathrm{mg} / \mathrm{L}$ (milligram per liter); and $\mathrm{pH}$ to the nearest $0.1 \mathrm{pH}$ units. Measurements of streamflow were made in accordance with standard USGS procedures (Rantz and others, 1982). Alkalinity measurements were made on filtered water samples using an incremental titration method (Shelton, 1994), and results were reported to the nearest $1 \mathrm{mg} / \mathrm{L}$ as calcium carbonate $\left(\mathrm{CaCO}_{3}\right)$.

Water samples were collected using 1-liter narrow-mouth acid-rinsed polyethylene bottles from a minimum of eight verticals in the cross section, using an equal-width-increment method described by Edwards and Glysson (1988), and composited into a 8liter polyethylene acid-rinsed churn splitter. Sample and compositing containers were prerinsed with native water prior to sample collection. Water samples were collected using clean procedures as outlined by Horowitz and others (1994). Samples were chilled on ice from time of sample collection until analysis, except when samples were processed. Processing of the field samples was accomplished either in the mobile field laboratory or in an area suitably clean for carrying out the filtering and preservation procedures.

Samples for major ions, nutrients, and trace elements in filtered water (operationally defined as dissolved) were passed through $0.45 \mu \mathrm{m}$ (micrometer) pore-size capsule filters into polyethylene bottles using procedures outlined by Horowitz and others (1994). Filtered-water trace-element samples were preserved with $0.5 \mathrm{~mL}$ (milliliter) of ultra-pure nitric acid per $250 \mathrm{~mL}$ of sample; nutrient samples were placed in dark brown polyethylene bottles and were chilled for preservation. All chemical samples were 


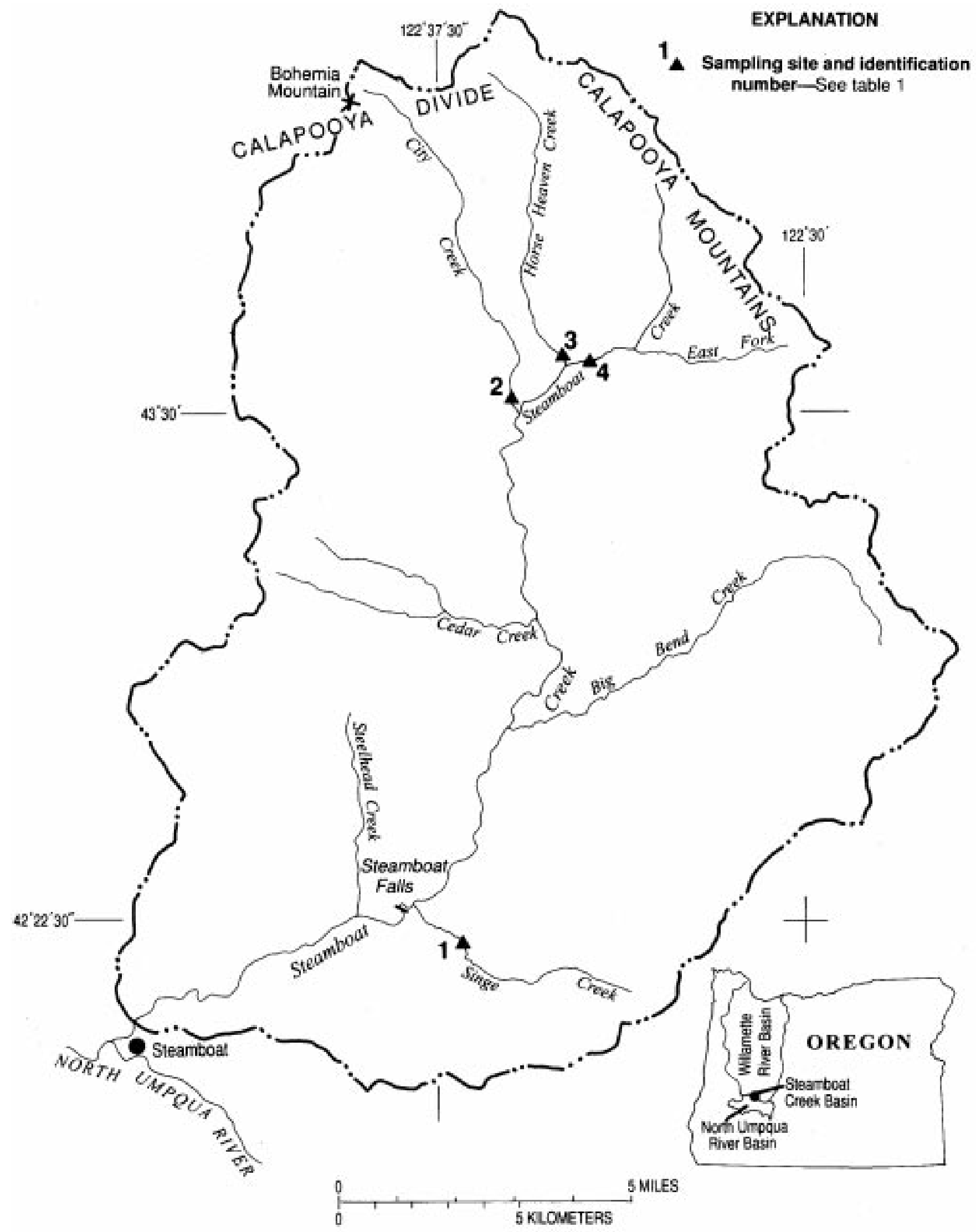

Figure 1. Sampling sites in the Steamboat Creek Basin, Oregon, September 1996. 
Table 1. Sampling sites in the Steamboat Creek Basin, Oregon, September 1996

[Site locations are shown in figure 1]

\begin{tabular}{|c|c|c|}
\hline $\begin{array}{l}\text { Site index } \\
\text { number }\end{array}$ & Site name & $\begin{array}{c}\text { Site location } \\
\text { Latitude / Longitude }\end{array}$ \\
\hline 1 & $\begin{array}{l}\text { Singe Creek near } \\
\text { Steamboat }\end{array}$ & $43^{\circ} 22^{\prime} 13^{\prime \prime} / 122^{\circ} 37^{\prime} 00^{\prime \prime}$ \\
\hline 2 & City Creek near Steamboat & $43^{\circ} 30^{\prime} 03^{\prime \prime} / 122^{\circ} 35^{\prime} 49^{\prime \prime}$ \\
\hline 3 & $\begin{array}{l}\text { Horse Heaven Creek near } \\
\text { Steamboat }\end{array}$ & $43^{\circ} 30^{\prime} 44^{\prime \prime} / 122^{\circ} 34^{\prime} 53^{\prime \prime}$ \\
\hline 4 & $\begin{array}{l}\text { Steamboat Creek near } \\
\text { Steamboat }\end{array}$ & $43^{\circ} 30^{\prime} 42^{\prime \prime} / 122^{\circ} 34^{\prime} 48^{\prime \prime}$ \\
\hline
\end{tabular}

shipped to the USGS National Water Quality Laboratory (NWQL) in Arvada, Colorado, for analysis according to methods outlined by Fishman (1993).

\section{Bottom Sediment}

Bottom-sediment samples were collected with a Teflon scoop and composited into 2-quart Pyrex containers from a minimum of 10 depositional areas at each site, using cleaning and sampling procedures outlined by Shelton and Capel (1994); two 2-quart Pyrex containers were filled with bottom sediment at each site. Only the surficial $2-3 \mathrm{~cm}$ (centimeter) of sediment was collected from each depositional area to ensure that only the most recently deposited materials would be sampled. The bottom-sediment samples were chilled until they were processed. The contents of the two 2-quart Pyrex containers were transferred to a 4-quart Pyrex container and then homogenized. Subsamples for trace-element analysis were processed by wet sieving (using native water) through a $62-\mu \mathrm{m}$ nylon mesh cloth, and contents were placed into acidrinsed $500 \mathrm{~mL}$, wide-mouth, polyethylene containers. After most of the sieved sediments had settled, the supernatant (native water) was decanted from the $<$ (less than) $62 \mu \mathrm{m}$ sediment fraction before being shipped to NWQL. Trace-element analysis were performed by the USGS Analytical Chemistry Services Group according to procedures established for evaluating the chemical composition of geologic materials (Arbogast, 1990).

\section{Quality Assurance}

To ensure the accuracy and precision of the analysis of the water and bottom-sediment samples, approximately 20 percent of the samples were collected and analyzed for the purpose of quality control
(Appendix B). The following types of quality-control samples were collected.

(1) Trace-element field blank samples. This type of sample required passing a volume of trace-element-free water through the same sampling, processing, and preservation method used for the native-water samples. The trace-element field blank sample was analyzed using an analytical method that provided lower MRLs than the nativewater samples to check for low-level trace-element contamination (Appendix A, table A-1). Results of this work showed no contamination, with the possible exception of some slight enrichment of calcium, silica, and zinc (Appendix B, table B-1). Concentrations of calcium, silica, and zinc observed in the field blank were below their MRLs used in the native-water samples, and therefore no corrections to the native-water results were necessary.

(2) Major-ion, nutrient, and trace-element field split samples. The volume of native water collected at Horse Heaven Creek was divided (split) into two samples and analyzed individually. Results of this work showed excellent agreement between the split-sample results, indicating a high degree of processing and laboratory precision (Appendix B, table B-2, and Appendix $\mathrm{C}$ table $\mathrm{C}-1$ and table C-2). A bottom-sediment trace-element sample from Horse Heaven Creek also was split; however, insufficient fine material $(<62 \mu \mathrm{m})$ was available for the second sample. In its place, a sample sieved at $<2 \mathrm{~mm}$ (millimeter) was analyzed and results were compared to those from the $<62 \mu \mathrm{m}$ fraction. Results of the bottom-sediment comparison showed that of the 13 trace elements commonly referred to in the literature, cadmium, copper, mercury, selenium, silver, and zinc were observed at concentrations from 1.5 to 4 times larger in the $<62 \mu \mathrm{m}$ fraction than in the $<2 \mathrm{~mm}$ fraction, whereas antimony, arsenic, chromium, cobalt, lead, manganese, and nickel were observed at about the same concentrations in both fractions; organic-carbon content was more than 12.5 times larger in the $<62 \mu \mathrm{m}$ sediment fraction (Appendix $\mathrm{C}$ table $\mathrm{C}-3$ ) than in the $<2 \mathrm{~mm}$ sediment fraction (Appendix B, table B-3).

A comparison was made between the balance of anions and cations in each filtered sample to check on the accuracy of the combined major-ion concentrations. Anion and cation microequivalent differences 
ranged from - 1.2 to 2.2 percent, and were considered excellent for the low-buffered water in the Steamboat Creek Basin.

\section{RESULTS}

\section{Water Chemistry}

Streamflow and field water-quality measurements were collected at the four sites in the Steamboat Creek Basin as given in Appendix C, table C-1. Streamflows in September 1996 were low, ranging from $0.71 \mathrm{ft}^{3} / \mathrm{s}$ (cubic feet per second) at City Creek to $1.81 \mathrm{ft}^{3} / \mathrm{s}$ at Singe Creek. Although streamflows were low, water temperatures remained moderately low, ranging from $12.1^{\circ} \mathrm{C}$ at Singe Creek to $15.0^{\circ} \mathrm{C}$ at City Creek. Dissolved-oxygen concentrations were close to saturation, ranging from 95 percent of saturation at Singe Creek to 99 percent of saturation at City Creek. Singe Creek had the largest specific conductance value (154 $\mu \mathrm{S} / \mathrm{cm})$ and the smallest $\mathrm{pH}(7.3 \mathrm{pH}$ units), whereas City Creek had the smallest specific conductance value $(43 \mu \mathrm{S} / \mathrm{cm})$ and Steamboat Creek had the largest $\mathrm{pH}$ (8.1 $\mathrm{pH}$ units). Anion and cation balances for the four sites were plotted on a trilinear diagram (fig. 2) to graphically represent the relative proportion of the ions. City Creek, Steamboat Creek, and Horse Heaven Creek had primarily calcium bicarbonate waters, with calcium contributing between 57 to 59 percent of the cation concentrations and bicarbonate contributing between 83 and 93 percent of the anion concentrations. Singe Creek had primarily a calcium sulfate water, with 61 percent calcium and 94 percent sulfate contributions; the bicarbonate ion in Singe Creek contributed only 3.8 percent of the anion concentration. The increased sulfate concentration and low alkalinity $\left(3 \mathrm{mg} / \mathrm{L}\right.$ as $\left.\mathrm{CaCO}_{3}\right)$ suggests that Singe Creek is probably receiving naturally occurring acidic waters. Of the four sites, Singe Creek had the largest total dissolved-solids concentration, and the largest major-ion concentrations for calcium, magnesium, potassium, silica, and sulfate, whereas Steamboat Creek had the largest sodium, bicarbonate, and chloride concentrations.

Nitrogen and phosphorus concentrations generally were low. All whole-water (unfiltered) concentrations of ammonia plus organic nitrogen were below their MRLs $(<0.2 \mathrm{mg} / \mathrm{L})$, whereas filtered-water nitrite plus nitrate concentrations ranged from $<0.005 \mathrm{mg} / \mathrm{L}$ in Singe Creek and Steamboat Creek to $0.032 \mathrm{mg} / \mathrm{L}$ in Horse Heaven Creek. Whole-water concentrations of phosphorus ranged from $0.002 \mathrm{mg} / \mathrm{L}$ in Singe Creek to $0.036 \mathrm{mg} / \mathrm{L}$ in Steamboat Creek, whereas soluble reactive (ortho) phosphorus concentrations ranged from $<0.001 \mathrm{mg} / \mathrm{L}$ in Singe Creek and City Creek to 0.021 $\mathrm{mg} / \mathrm{L}$ in Steamboat Creek.

\section{Trace Elements}

\section{Water}

Filtered-water samples collected at the four Steamboat Creek Basin sites were analyzed for 18 trace elements (Appendix C, table C-2). Only six elements-aluminum, barium, cobalt, iron, manganese, and zinc-were detected at concentrations above their MRLs (table 2). All six of these were detected in Singe Creek at concentrations generally larger than those observed at the other three sites; aluminum, barium, and zinc were detected in City Creek at concentrations larger than those observed at Horse Heaven Creek and Steamboat Creek. Of the six detected trace elements, chronic aquatic life toxicity criteria have been developed only for iron and zinc (U.S. Environmental Protection Agency, 1986); none of the detected

Table 2. Concentrations of trace elements in filtered water samples collected from the Steamboat Creek Basin, September 9-13, 1996

[Site locations are shown in figure 1; element concentrations in micrograms per liter]

\begin{tabular}{clcccccc}
\hline $\begin{array}{c}\text { Site index } \\
\text { number }\end{array}$ & \multicolumn{1}{c}{ Site name } & Aluminum & Barium & Cobalt & Iron & Manganese & Zinc \\
\hline 1 & Singe Creek & 8 & 31 & 1 & 11 & 100 & 4 \\
2 & City Creek & 4 & 8 & $<1$ & $<3$ & $<1$ & 4 \\
3 & Horse Heaven Creek & 2 & 6 & $<1$ & $<3$ & $<1$ & 3 \\
4 & Steamboat Creek & 2 & 2 & $<1$ & $<3$ & $<1$ & $<1$ \\
\hline
\end{tabular}




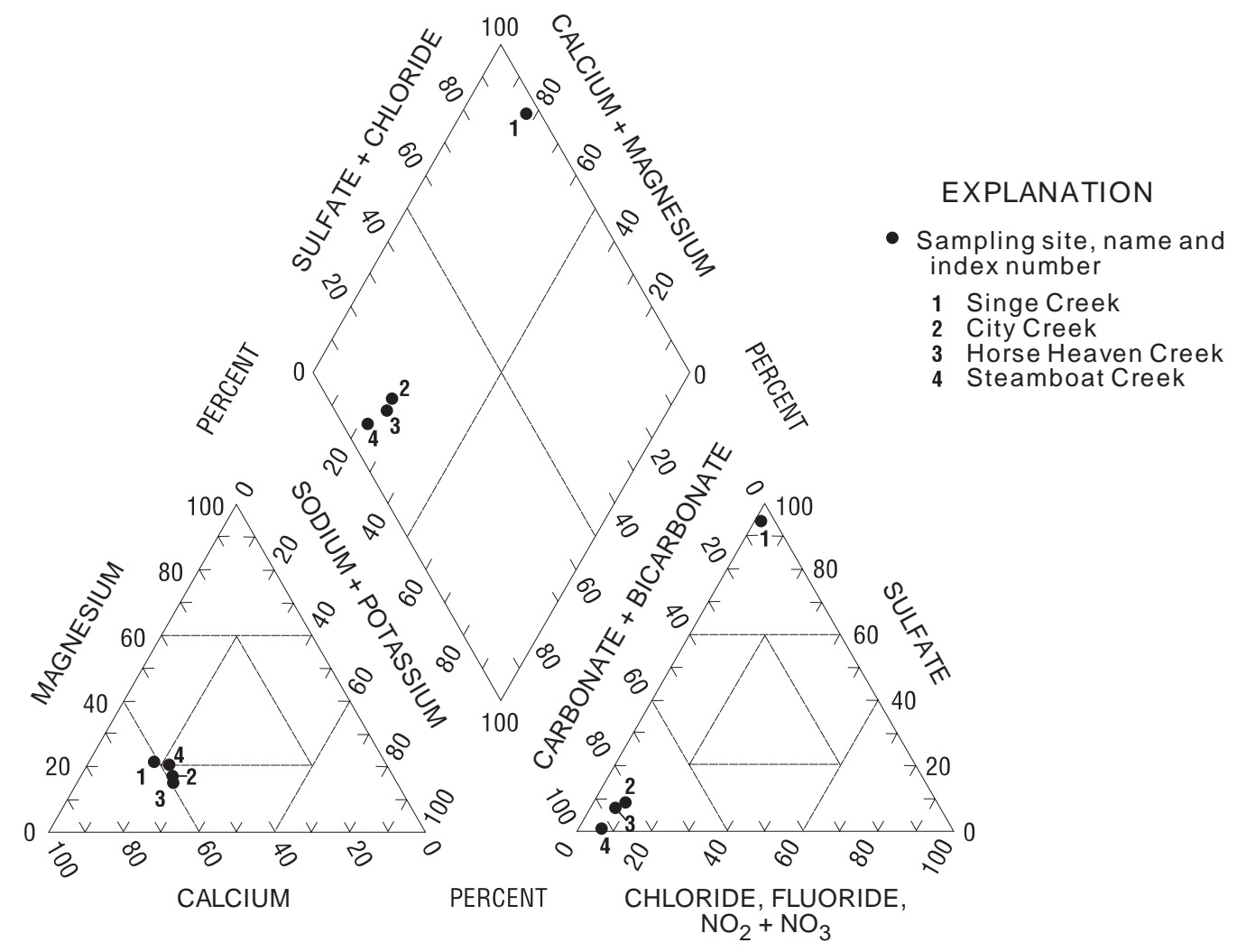

Figure 2. Trilinear diagram of major-ion concentrations in filtered water samples collected from the Steamboat Creek Basin, Oregon, September 9-13, 1996. (Numbers in figure refer to site index numbers shown in figure 1 and listed in table 1.)

concentrations exceeded the criteria levels for either iron or zinc at any site.

\section{Bottom Sediment}

Bottom sediments were analyzed for 44 trace elements plus inorganic and organic carbon (Appendix $\mathrm{C}$, table $\mathrm{C}-3)$. Of particular interest were concentrations for 13 trace elements - antimony, arsenic, cadmium, chromium, cobalt, copper, lead, manganese, mercury, nickel, selenium, silver, and zinc_-which are frequently associated with human activities; organic carbon content is also of interest because of its potential effect on aquatic life (Persaud and others, 1993). Bottom-sediment concentrations for antimony, arsenic, cadmium, copper, lead, mercury, zinc, and organic carbon were largest in City Creek; cobalt and selenium concentrations were largest in Singe Creek; chromium and nickel were largest in Steamboat Creek; and manganese and silver ranked highest in Horse Heaven Creek.
To determine how the trace-element concentrations at each site ranked overall against one another, concentrations for each of the 13 trace elements and organic carbon were compared among sites and each constituent assigned a ranking from 1 to 4 (smallest to largest concentration, respectively). The rankings for the 14 constituents (13 trace elements plus organic carbon) for each site were summed and their overall mean rankings computed. City Creek had the largest overall mean concentration ranking (3.2), followed by Horse Heaven Creek (2.8), Singe Creek (2.3), and Steamboat Creek (1.8), respectively. The overall mean ranking for City Creek was determined to be statistically larger (p $<0.05$ ) than the mean ranking for Steamboat Creek, but not from the mean rankings of either Horse Heaven Creek or Singe Creek.

To determine whether trace-element concentrations and organic carbon content in bottom sediment from the four sites in the Steamboat Creek Basin were enriched compared with those in other areas of western Oregon, a comparison was made with concentrations observed in the Willamette River Basin, as part 
of the Willamette National Water-Quality Assessment (NAWQA) study, 1992-95 (Wentz and McKenzie, 1991). Normal probability plots were prepared for the 13 trace elements and organic carbon analyzed from 52 sites in the Willamette River Basin, and break-point concentrations, similar to those computed by Rickert and others (1977) and Rinella (1993), and illustrated in Appendix D, were calculated and compared to concentrations observed in the Steamboat Creek Basin (table 3). Constituent concentrations in the Steamboat Creek Basin above the Willamette River Basin breakpoint values were considered to be enriched. Thirteen of the 14 constituents exceeded break-point concentrations at 1 or more sites in the Steamboat Creek Basin; the only Willamette Basin break-point concentration not exceeded was for chromium. Concentrations of 11 elements in City Creek and Horse Heaven Creek - antimony, arsenic, cadmium, copper, lead, manganese (Horse Heaven Creek only), mercury, selenium, silver, zinc, and organic carbon (City Creek only)—exceeded Willamette River Basin break-point values; concentrations for 5 elements in Singe Creek - antimony, arsenic, cobalt, mercury, and selenium-exceeded Willamette River Basin break-point values; and only two elements in Steamboat Creek-antimony and nickel—exceeded Willamette River Basin break-point values (table 3).

River-bottom-sediment data from the four sites in the Steamboat Creek Basin also were compared with Canadian Council of Ministers of the Environment interim sediment-quality guidelines for the protection of aquatic life (Environment Canada, 1995). The interim Canadian sediment-quality guidelines used in this study were the threshold effects level (TEL) values, which are the concentrations below which adverse effects are expected to occur rarely to aquatic life. The TEL guideline concentrations are based on analysis of trace-element concentrations in bulk river-bottom-sediment samples as compared to the $<62 \mu \mathrm{m}$ size river-bottom-sediment materials analyzed in this study. Because the $<62 \mu \mathrm{m}$-size fraction tends to have higher concentrations than bulk sediment, element concentrations analyzed in this study may in some instances exceed TEL guideline values solely as a result of the quantity of the fine-grainedsized materials in the sample. Consequently, trace-element concentrations exceeding the TEL guidance values should be used only as an indicator of potential sediment-quality problems that may warrant further examination. Bottom-sediment TEL concentrations have been established for only 8 of the 14 constituents discussed earlier-arsenic, cadmium, chromium, copper, lead, mercury, nickel, and zinc. Bottom-sediment concentrations for these eight constituents exceeded TEL guidance values at one or more sites in the Steamboat Creek Basin (table 3). Bottom-sediment concentrations for six of the constituents in City Creek and Horse Heaven Creek-arsenic, cadmium, copper, lead, mercury, and zinc-exceeded TEL concentrations, whereas only four elements between Singe Creek and Steamboat Creek-arsenic, chromium, copper (Singe Creek only), and nickel—exceeded TEL concentrations (table 3 ).

\section{SUMMARY}

Four streams in the Steamboat Creek Basin, Oregon, were sampled during September 9-13, 1996, to describe current concentrations of major ions, nutrients, and trace elements in river water and bottom sediments. Three of the sites sampled were located near the mouths of tributaries to Steamboat Creek-Singe Creek, City Creek, and Horse Heaven Creek-and one site on Steamboat Creek was located farther upstream.

Streamflow and specific conductance in Singe Creek were larger than those observed at the other three sites, whereas temperature, dissolved-oxygen saturation, and $\mathrm{pH}$ values were smallest in Singe Creek. Examination of major-ion concentrations showed Singe Creek to be a predominantly calcium sulfate water system, whereas the other three streams were predominantly calcium bicarbonate water systems. Of the four sites examined, Singe Creek had the largest total dissolved-solids concentration, and the largest major-ion concentrations for calcium, magnesium, potassium, silica, and sulfate. Nitrogen and phosphorus concentrations (ammonia plus organic nitrogen, nitrite plus nitrate, phosphorus, and soluble reactive phosphorus) generally were smaller in Singe Creek than at the other three sites. Only six trace elements-aluminum, barium, cobalt, iron, manganese, and zinc-were detected in surface waters, and all six were detected in Singe Creek at concentrations generally larger than those observed in the other three sites.

Of the 14 constituents most frequently associated with human activities and aquatic life impacts, bottom-sediment concentrations for antimony, arsenic, cadmium, copper, lead, mercury, zinc and organic carbon were largest in City Creek. Concentrations for 11 constituents in City Creek and Horse 
Table 3. Concentrations of trace elements in bottom sediment in the Steamboat Creek Basin that exceeded either Willamette River Basin break-point values or Canadian Council of Ministers of the Environment (Environmental Canada, 1995) interim threshold effect levels (TEL); TEL values are guideline concentrations below which adverse effects are expected to occur rarely to aquatic life

[For site location see figure 1. Elemental concentrations are in micrograms per gram, except for $\mathrm{C}$ which is in percent; $\mathrm{Sb}$, antimony; $\mathrm{As}$, arsenic; $\mathrm{Cd}$, cadmium; Cr, chromium; Co, cobalt;

$\mathrm{Cu}$, copper; $\mathrm{Pb}$, lead; $\mathrm{Mn}$, manganese; $\mathrm{Hg}$, mercury; $\mathrm{Ni}$, nickel; Se, selenium; Ag, silver; $\mathrm{Zn}$, zinc; and $\mathrm{C}$, organic carbon; na, not available; *, less than the break-point value and the sedimentquality guideline; bold number, exceeded both the break-point value and the sediment-quality guideline. Willamette River Basin break-point concentrations based on <62 $\mu \mathrm{m}$ materials; Interim Council of Ministers of the Environment TELs guidelines based on unsieved bulk materials]

\begin{tabular}{|c|c|c|c|c|c|c|c|c|c|c|c|c|c|c|c|}
\hline \multirow{2}{*}{$\begin{array}{c}\text { Site } \\
\text { index } \\
\text { no. }\end{array}$} & \multirow{2}{*}{ Site name } & \multicolumn{14}{|c|}{ Element } \\
\hline & & Sb & As & Cd & $\mathrm{Cr}$ & Co & $\mathrm{Cu}$ & $\mathrm{Pb}$ & Mn & $\mathrm{Hg}$ & $\mathrm{Ni}$ & Se & $\mathrm{Ag}$ & $\mathrm{Zn}$ & C \\
\hline 1 & Singe Creek & 2.0 & 23 & $*$ & 64 & 31 & 37 & $*$ & $*$ & 0.14 & 24 & 1.2 & $*$ & $*$ & $*$ \\
\hline 2 & City Creek & 9.0 & 24 & 12 & $*$ & $*$ & 86 & 240 & $*$ & .67 & $*$ & .4 & 0.8 & 690 & 6.75 \\
\hline 3 & Horse Heaven Creek & 4.0 & 22 & 3.7 & $*$ & $*$ & 58 & 44 & 1,500 & .43 & $*$ & .4 & 1.0 & 430 & $*$ \\
\hline 4 & Steamboat Creek & 2.0 & 10 & $*$ & 92 & $*$ & $*$ & $*$ & $*$ & $*$ & 33 & $*$ & $*$ & $*$ & $*$ \\
\hline \multicolumn{2}{|c|}{$\begin{array}{l}\text { Willamette River Basin } \\
\text { break-point values }\end{array}$} & 1.3 & 10 & .5 & 100 & 30 & 50 & 30 & 1,400 & .11 & 30 & .35 & .3 & 200 & 6.4 \\
\hline \multicolumn{2}{|c|}{$\begin{array}{l}\text { Canadian Council of Ministers of } \\
\text { the Environment TEL guidelines }\end{array}$} & na & 5.9 & .596 & 37.3 & na & 35.7 & 35.0 & na & .174 & 18.0 & na & na & 123 & na \\
\hline
\end{tabular}


Heaven Creek - antimony, arsenic, cadmium, copper, lead, manganese (Horse Heaven Creek only), mercury, selenium, silver, zinc, and organic carbon (City Creek only)—exceeded break-point concentrations considered as levels of enrichment in the Willamette River Basin. Also, bottom-sediment concentrations for six trace elements in City Creek and Horse Heaven Creek-arsenic, cadmium, copper, lead, mercury, and zinc-exceeded interim Canadian threshold effect level concentrations established for the protection of aquatic life.

\section{REFERENCES CITED}

Arbogast, B.F. (ed), 1990, Quality assurance manual for the Branch of Geochemistry: U.S. Geological Survey Open-File Report, 90-688, 184 p.

Edwards, T.K., and Glysson, D.G., 1988, Field methods for measurement of fluvial sediment: U.S. Geological Survey Open-File Report 86-531, 118 p.

Environment Canada, 1995, Interim sediment quality guidelines: Ottawa, Ontario, Ecosystem Conservation Directorate, Evaluation and Interpretation Branch, Soil and Sediment Quality Section, Guidelines Division, Environment Canada, 8 p. plus appendices.

Fishman, M.J., 1993, Methods of analysis by the U.S. Geological Survey National Water-Quality Laboratory-Determination of inorganic and organic substances in water and fluvial sediments: U.S. Geological Survey Open-File Report 93-125, $217 \mathrm{p}$.

Horowitz, A.J., Demas, C.R., Fitzgerald, K.K., Miller, T.L., and Rickert, D.A., 1994, U.S. Geological Survey protocol for the collection and processing of surface-water samples for the subsequent determination of inorganic constituents in filtered water: U.S. Geological Survey Open-File Report 94-539, $57 \mathrm{p}$.
Persaud, D., Jaagumagi, R., and Hayton, A., 1993, Guidelines for the protection and management of aquatic sediment quality in Ontario: Ontario Ministry of the Environment and Energy, Water Resources Branch, Ontario, Canada, 16 p. plus appendices.

Rantz, S.E., and others, 1982, Measurement and computation of streamflow: U.S. Geological Survey Water Supply Paper 2175, 2 vol., 631 p.

Rickert, D.A., Kennedy, V.C., McKenzie, S.W., and Hines, W.G., 1977, A synoptic survey of trace metals in bottom sediments of the Willamette River, Oregon: U.S. Geological Survey Circular 715-F, $27 \mathrm{p}$.

Rinella, F.A., 1993, Evaluation of organic compounds and trace elements in Amazon Creek basin, Oregon, September 1990: U.S. Geological Survey Water-Resources Investigation Report 93-4041, $41 \mathrm{p}$.

Shelton L.R., 1994, Field guide for collecting and processing stream-water samples for the National Water-Quality Assessment Program: U.S. Geological Survey Open-File Report 94-455, 42 p.

Shelton, L.R., and Capel, P.D., 1994, Guidelines for collecting and processing samples of stream bed sediment for analysis of trace elements and organic contaminants for the National Water-Quality Assessment Program: U.S. Geological Survey Open-File Report 94-458, 20 p.

Timme, P.J., 1995, National Water Quality Laboratory 1995 Service Catalog: U.S. Geological Survey Open-File Report 95-352, 120 p.

U.S. Environmental Protection Agency, 1986, Quality criteria for water-1986 (two updates): Washington, D.C., EPA 440/5-86-001, May 1986.

Wentz, D.A., and McKenzie, S.W., 1991, National Water-Quality Assessment program-The Willamette Basin, Oregon: U.S. Geological Survey Open-File Report 91-167, 2 p. 
Page Intentionally Blank 
APPENDIX A 
Page Intentionally Blank 


\section{APPENDIX A. LIST OF CONSTITUENTS ANALYZED AND THEIR MINIMUM REPORTING LEVELS}

Table A-1. List of constituents, U.S. Geological Survey laboratory codes, U.S. Environmental Protection Agency's Storage and Retrieval (STORET) database codes, and minimum reporting levels (MRLs) for constituents analyzed in the trace-element, field-blank, water sample [Lab, laboratory; CAS, Chemical Abstracts Service; concentrations in micrograms per liter, except for calcium, magnesium, silica, and sodium which are in milligrams per liter]

\section{Schedule 172}

Category: Inorganics: Major Ions and Trace Metals

\begin{tabular}{|c|c|c|c|c|}
\hline $\begin{array}{l}\text { Lab } \\
\text { code }\end{array}$ & $\begin{array}{c}\text { STORET } \\
\text { code }\end{array}$ & $\begin{array}{l}\text { CAS } \\
\text { number }\end{array}$ & Constituent & MRL \\
\hline 1877 & 01106 & $7429-90-5$ & Aluminum & 0.3 \\
\hline 1885 & 01049 & $7439-92-1$ & Lead & 0.3 \\
\hline 1894 & 01020 & $7440-42-8$ & Boron & 2.0 \\
\hline 1880 & 01010 & $7440-41-7$ & Beryllium & 0.2 \\
\hline 1886 & 01056 & $7439-96-5$ & Manganese & 0.1 \\
\hline 1892 & 01080 & $7440-24-6$ & Strontium & 0.1 \\
\hline 1879 & 01005 & $7440-39-3$ & Barium & 0.2 \\
\hline 1891 & 01090 & $7440-66-6$ & Zinc & 0.5 \\
\hline 1888 & 01065 & $7440-02-0$ & Nickel & 0.5 \\
\hline 1897 & 00925 & $7439-95-4$ & Magnesium & 0.001 \\
\hline 1890 & 22703 & $7440-61-1$ & Uranium, natural & 0.2 \\
\hline 1882 & 01030 & $7440-47-3$ & Chromium & 0.2 \\
\hline 1881 & 01025 & $7440-43-9$ & Cadmium & 0.3 \\
\hline 1887 & 01060 & $7439-98-7$ & Molybdenum & 0.2 \\
\hline 1899 & 00955 & $7631-86-9$ & Silica & 0.02 \\
\hline 1893 & 01057 & $7440-28-0$ & Thallium & 0.1 \\
\hline 1884 & 01040 & $7440-50-8$ & Copper & 0.2 \\
\hline 1895 & 00915 & $7440-70-2$ & Calcium & 0.002 \\
\hline 1896 & 01046 & $7439-89-6$ & Iron & 3.0 \\
\hline 1889 & 01075 & $7440-22-4$ & Silver & 0.2 \\
\hline 1878 & 01095 & $7440-36-0$ & Antimony & 0.2 \\
\hline 1898 & 00930 & $7440-23-5$ & Sodium & 0.025 \\
\hline 1883 & 01035 & $7440-48-4$ & Cobalt & 0.2 \\
\hline \multicolumn{5}{|c|}{ Constituents added to schedule } \\
\hline 112 & 01000 & $7440-38-2$ & Arsenic & 1.0 \\
\hline 87 & 01145 & $7782-49-2$ & Selenium & 1.0 \\
\hline
\end{tabular}




\section{APPENDIX A. LIST OF CONSTITUENTS ANALYZED AND THEIR MINIMUM REPORTING LEVELS-Continued}

Table A-2. U.S. Geological Survey laboratory codes, U.S. Environmental Protection Agency Storage and Retrieval (STORET) database codes, and minimum reporting levels (MRLs) for major ion and nutrient constituents analyzed in water samples

[CAS, Chemical Abstracts Service; concentrations in milligrams per liter]

\section{Schedule 2701}

Category: Inorganics: Major Ions

\begin{tabular}{|c|c|c|c|c|}
\hline $\begin{array}{l}\text { Lab } \\
\text { code }\end{array}$ & $\begin{array}{l}\text { STORET } \\
\text { code }\end{array}$ & $\begin{array}{l}\text { CAS } \\
\text { number }\end{array}$ & Constituent & MRL \\
\hline 663 & 00925 & $7439-95-4$ & Magnesium & 0.01 \\
\hline 31 & 00950 & $16984-48-8$ & Fluoride & 0.1 \\
\hline 667 & 00955 & $7631-86-9$ & Silica & 0.01 \\
\hline 1572 & 00945 & $14808-79-8$ & Sulfate & 0.1 \\
\hline 70 & 90410 & $471-34-1$ & Alkalinity & 1 \\
\hline 675 & 00930 & $7440-23-5$ & Sodium & 0.2 \\
\hline 27 & 70300 & & Residue, 180 degrees Celsius & 1 \\
\hline 648 & 01056 & $7439-96-5$ & Manganese & 1 \\
\hline 645 & 01046 & $7439-89-6$ & Iron & 3 \\
\hline 1571 & 00940 & $16887-00-6$ & Chloride & 0.1 \\
\hline 659 & 00915 & $7440-70-2$ & Calcium & 0.02 \\
\hline 54 & 00935 & $7440-09-7$ & Potassium & 0.1 \\
\hline
\end{tabular}

Schedule 1119

Category: Inorganics: Nutrients

\begin{tabular}{lllll}
\hline Lab & STORET & CAS & & \\
code & code & number & Constituent & MRL \\
\hline
\end{tabular}

$\begin{array}{rrrll}1985 & 00623 & 17778-88-0 & \text { Nitrogen, ammonia + organic nitrogen } & 0.2 \\ 1979 & 00631 & & \text { Nitrogen, nitrite + nitrate } & 0.005 \\ 1981 & 00666 & 7723-14-0 & \text { Phosphorus } & 0.001 \\ 1982 & 00665 & 7723-14-0 & \text { Phosphorus, total } & 0.001 \\ 1977 & 00613 & 14797-65-0 & \text { Nitrogen, nitrite } & 0.001 \\ 1980 & 00608 & 7664-41-7 & \text { Nitrogen, ammonia } & 0.002 \\ 1978 & 00671 & 14265-44-2 & \text { Phosphorus, phosphate, ortho } & 0.001 \\ 1986 & 00625 & 17778-88-0 & \text { Nitrogen, ammonia + organic nitrogen } & 0.2\end{array}$




\section{APPENDIX A. LIST OF CONSTITUENTS ANALYZED AND THEIR MINIMUM REPORTING LEVELS-Continued}

Table A-3. U.S. Geological Survey laboratory codes, U.S. Environmental Protection Agency Storage and Retrieval (STORET) database codes, and minimum reporting levels

(MRLs) for trace elements analyzed in water samples

[CAS, Chemical Abstracts Service; concentrations in micrograms per liter]

\begin{tabular}{|c|c|c|c|c|}
\hline \multicolumn{5}{|c|}{ Schedule 2703} \\
\hline \multicolumn{3}{|c|}{ Category: Inorganics: } & \multicolumn{2}{|l|}{ Trace Metals } \\
\hline Lab & STORET & CAS & & \\
\hline code & code & number & Constituent & MRL \\
\hline 1784 & 01106 & $7429-90-5$ & Aluminum & 1 \\
\hline 1785 & 01095 & $7440-36-0$ & Antimony & 1 \\
\hline 112 & 01000 & $7440-38-2$ & Arsenic & 1 \\
\hline 1786 & 01005 & $7440-39-3$ & Barium & 1 \\
\hline 1787 & 01010 & $7440-41-7$ & Beryllium & 1 \\
\hline 1788 & 01025 & $7440-43-9$ & Cadmium & 1 \\
\hline 1789 & 01030 & $7440-47-3$ & Chromium & 1 \\
\hline 1790 & 01035 & $7440-48-4$ & Cobalt & 1 \\
\hline 1791 & 01040 & $7440-50-8$ & Copper & 1 \\
\hline 1792 & 01049 & $7439-92-1$ & Lead & 1 \\
\hline 1793 & 01056 & $7439-96-5$ & Manganese & 1 \\
\hline 1794 & 01060 & $7439-98-7$ & Molybdenum & 1 \\
\hline 1795 & 01065 & $7440-02-0$ & Nickel & 1 \\
\hline 87 & 01145 & $7782-49-2$ & Selenium & 1 \\
\hline 1796 & 01075 & $7440-22-4$ & Silver & 1 \\
\hline 1797 & 22703 & $7440-61-1$ & Uranium, natural & 1 \\
\hline 1798 & 01090 & $7440-66-6$ & Zinc & 1 \\
\hline
\end{tabular}




\section{APPENDIX A. LIST OF CONSTITUENTS ANALYZED AND THEIR MINIMUM REPORTING LEVELS-Continued}

Table A-4. U.S. Geological Survey laboratory codes, U.S. Environmental Protection Agency Storage and Retrieval (STORET) database codes, and minimum reporting levels (MRLs) for trace elements analyzed in bottom-sediment samples

[CAS, Chemical Abstracts Service; concentrations in micrograms per gram $(\mu \mathrm{G} / \mathrm{G})$ or in percent (PCT)]

\begin{tabular}{|c|c|c|c|c|c|}
\hline $\begin{array}{l}\text { Scheo } \\
\text { Categ }\end{array}$ & $\begin{array}{r}\text { de } 2400 \\
\text { ory: Ino } \\
\text { bot }\end{array}$ & $\begin{array}{l}\text { rganics: Major } \\
\text { tom sediment }\end{array}$ & Ions and Trace Metals in less & than 63 & micrometer \\
\hline $\begin{array}{l}\text { Lab } \\
\text { code }\end{array}$ & $\begin{array}{l}\text { STORET } \\
\text { code }\end{array}$ & $\begin{array}{l}\text { CAS } \\
\text { number }\end{array}$ & Constituent & MRL & $\begin{array}{l}\text { Reporting } \\
\text { unit }\end{array}$ \\
\hline 1772 & 34955 & $7440-22-4$ & Silver & 0.1 & $\mu \mathrm{G} / \mathrm{G}$ \\
\hline 1774 & 34910 & $7439-97-6$ & Mercury & 0.02 & $\mu \mathrm{G} / \mathrm{G}$ \\
\hline 1753 & 34860 & $7440-55-3$ & Gallium & 4 & $\mu \mathrm{G} / \mathrm{G}$ \\
\hline 1780 & 34970 & $7704-34-9$ & Sulfur & 0.05 & $\mathrm{PCT}$ \\
\hline 1778 & 35000 & $7440-61-1$ & Uranium & 0.05 & $\mu \mathrm{G} / \mathrm{G}$ \\
\hline 1752 & 34855 & $7440-53-1$ & Europium & 2 & $\mu \mathrm{G} / \mathrm{G}$ \\
\hline 1743 & 49274 & $7440-32-6$ & Titanium & 0.005 & $\mathrm{PCT}$ \\
\hline 1758 & 34915 & $7439-98-7$ & Molybdenum & 2 & $\mu \mathrm{G} / \mathrm{G}$ \\
\hline 1751 & 34850 & $7440-50-8$ & Copper & 1 & $\mu \mathrm{G} / \mathrm{G}$ \\
\hline 1771 & 35020 & $7440-66-6$ & Zinc & 4 & $\mu \mathrm{G} / \mathrm{G}$ \\
\hline 1740 & 34900 & $7439-95-4$ & Magnesium & 0.005 & $\mathrm{PCT}$ \\
\hline 1754 & 34875 & $7440-60-0$ & Holmium & 4 & $\mu \mathrm{G} / \mathrm{G}$ \\
\hline 1737 & 34830 & $7440-70-2$ & Calcium & 0.005 & $\mathrm{PCT}$ \\
\hline 1756 & 34895 & $7439-93-2$ & Lithium & 2 & $\mu \mathrm{G} / \mathrm{G}$ \\
\hline 1773 & 34825 & $7440-43-9$ & Cadmium & 0.1 & $\mu \mathrm{G} / \mathrm{G}$ \\
\hline 1736 & 34790 & $7429-90-5$ & Aluminum & 0.005 & $\mathrm{PCT}$ \\
\hline 1742 & 34935 & $7723-14-0$ & Phosphorus & 0.005 & $\mathrm{PCT}$ \\
\hline 1770 & 35015 & $7440-64-4$ & Ytterbium & 1 & $\mu \mathrm{G} / \mathrm{G}$ \\
\hline 1762 & 34890 & $7439-92-1$ & Lead & 4 & $\mu \mathrm{G} / \mathrm{G}$ \\
\hline 1779 & 34980 & $7440-29-1$ & thorium & 1 & $\mu \mathrm{G} / \mathrm{G}$ \\
\hline 1766 & 34975 & & Tantalum & 40 & $\mu \mathrm{G} / \mathrm{G}$ \\
\hline 1763 & 34945 & $7440-20-2$ & Scandium & 2 & $\mu \mathrm{G} / \mathrm{G}$ \\
\hline 1760 & 34920 & $7440-00-8$ & Neodymium & 4 & $\mu \mathrm{G} / \mathrm{G}$ \\
\hline 1776 & 34795 & $7440-36-0$ & Antimony & 0.1 & $\mu \mathrm{G} / \mathrm{G}$ \\
\hline 1748 & 34835 & $7440-45-1$ & Cerium & 4 & $\mu \mathrm{G} / \mathrm{G}$ \\
\hline 1775 & 34800 & $7440-38-2$ & Arsenic & 0.1 & $\mu \mathrm{G} / \mathrm{G}$ \\
\hline 1759 & 34930 & $7440-03-1$ & Niobium & 4 & $\mu \mathrm{G} / \mathrm{G}$ \\
\hline 1765 & 34965 & $7440-24-6$ & Strontium & 2 & $\mu \mathrm{G} / \mathrm{G}$ \\
\hline 1747 & 34816 & $7440-69-9$ & Bismuth & 10 & $\mu \mathrm{G} / \mathrm{G}$ \\
\hline 1741 & 34960 & $7440-23-5$ & Sodium & 0.005 & $\mathrm{PCT}$ \\
\hline 1761 & 34925 & $7440-02-0$ & Nickel & 2 & $\mu \mathrm{G} / \mathrm{G}$ \\
\hline 1745 & 34805 & $7440-39-3$ & Barium & 1 & $\mu \mathrm{G} / \mathrm{G}$ \\
\hline 1768 & 35005 & $7440-62-2$ & Vanadium & 2 & $\mu \mathrm{G} / \mathrm{G}$ \\
\hline 1782 & 49269 & & Inorganic carbon & 0.01 & $\mathrm{PCT}$ \\
\hline 1755 & 34885 & $7439-91-0$ & Lanthanum & 2 & $\mu \mathrm{G} / \mathrm{G}$ \\
\hline 1777 & 34950 & $7782-49-2$ & Selenium & 0.1 & $\mu \mathrm{G} / \mathrm{G}$ \\
\hline 1744 & 34870 & $7440-57-5$ & Gold & 8 & $\mu \mathrm{G} / \mathrm{G}$ \\
\hline 1749 & 34845 & $7440-47-3$ & Chromium & 1 & $\mu \mathrm{G} / \mathrm{G}$ \\
\hline 1783 & 49266 & & Organic carbon & 0.01 & $\mathrm{PCT}$ \\
\hline 1764 & 34985 & $7440-31-5$ & $\operatorname{Tin}$ & 5 & $\mu \mathrm{G} / \mathrm{G}$ \\
\hline 1739 & 34940 & $7440-09-7$ & Potassium & 0.05 & $\mathrm{PCT}$ \\
\hline 1781 & 49267 & & Total carbon & 0.01 & $\mathrm{PCT}$ \\
\hline 1750 & 34840 & $7440-48-4$ & Cobalt & 1 & $\mu \mathrm{G} / \mathrm{G}$ \\
\hline 1769 & 35010 & $7440-65-5$ & Yttrium & 2 & $\mu / G$ \\
\hline 1746 & 34810 & $7440-41-7$ & Beryllium & 1 & $\mu \mathrm{G} / \mathrm{G}$ \\
\hline 1757 & 34905 & $7439-96-5$ & Manganese & 4 & $\mu \mathrm{G} / \mathrm{G}$ \\
\hline 1738 & 34880 & $7439-89-6$ & Iron & 0.005 & $\mathrm{PCT}$ \\
\hline
\end{tabular}


APPENDIX B 
Page Intentionally Blank 


\section{APPENDIX B. CHEMICAL ANALYSIS OF THE QUALITY ASSURANCE SAMPLES}

Table B-1. Concentrations of trace elements in field-blank water sample

[Dissolved, operationally defined as water that has been passed though a 0.45 micrometer filter; constituent concentrations in $\mathrm{MG} / \mathrm{L}$, milligrams per liter or $\mu \mathrm{G} / \mathrm{L}$, micrograms per liter; number in parenthesis is the U.S. Environmental Protection Agency Storage and Retrieval (STORET) database code]

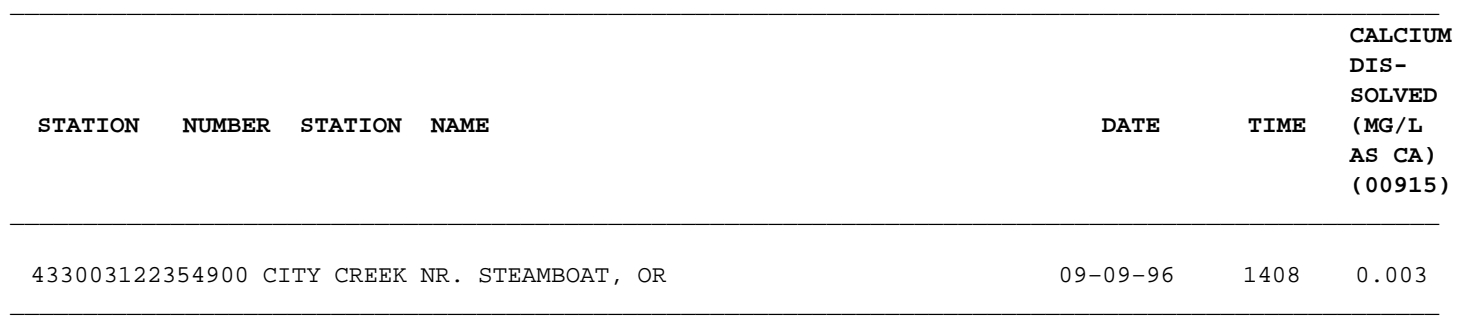

\begin{tabular}{|c|c|c|c|c|c|c|c|c|c|c|}
\hline STATION & NUMBER & DATE & $\begin{array}{c}\text { MAGNE- } \\
\text { SIUM, } \\
\text { DIS- } \\
\text { SOLVED } \\
\text { (MG/L } \\
\text { AS MG) } \\
(00925)\end{array}$ & $\begin{array}{l}\text { SODIUM, } \\
\text { DIS- } \\
\text { SOLVED } \\
\text { (MG/L } \\
\text { AS NA) } \\
(00930)\end{array}$ & $\begin{array}{l}\text { SILICA, } \\
\text { DIS- } \\
\text { SOLVED } \\
\text { (MG/L } \\
\text { AS } \\
\text { SIO2) } \\
(00955)\end{array}$ & $\begin{array}{c}\text { ALUM- } \\
\text { INUM, } \\
\text { DIS- } \\
\text { SOLVED } \\
(\mu G / L \\
\text { AS AL) } \\
(01106)\end{array}$ & $\begin{array}{c}\text { ANTI- } \\
\text { MONY, } \\
\text { DIS- } \\
\text { SOLVED } \\
(\mu G / L \\
\text { AS SB) } \\
(01095)\end{array}$ & $\begin{array}{c}\text { ARSENIC } \\
\text { DIS- } \\
\text { SOLVED } \\
(\mu G / L \\
\text { AS AS) } \\
(01000)\end{array}$ & $\begin{array}{c}\text { BARIUM, } \\
\text { DIS- } \\
\text { SOLVED } \\
(\mu G / L \\
\text { AS BA) } \\
(01005)\end{array}$ & $\begin{array}{l}\text { BERYL- } \\
\text { LIUM, } \\
\text { DIS- } \\
\text { SOLVED } \\
(\mu G / L \\
\text { AS BE) } \\
(01010)\end{array}$ \\
\hline 43300312 & 354900 & $09-09-96$ & $<0.001$ & $<0.03$ & 0.033 & $<0.3$ & $<0.2$ & $<1$ & $<0.2$ & $<0.2$ \\
\hline
\end{tabular}

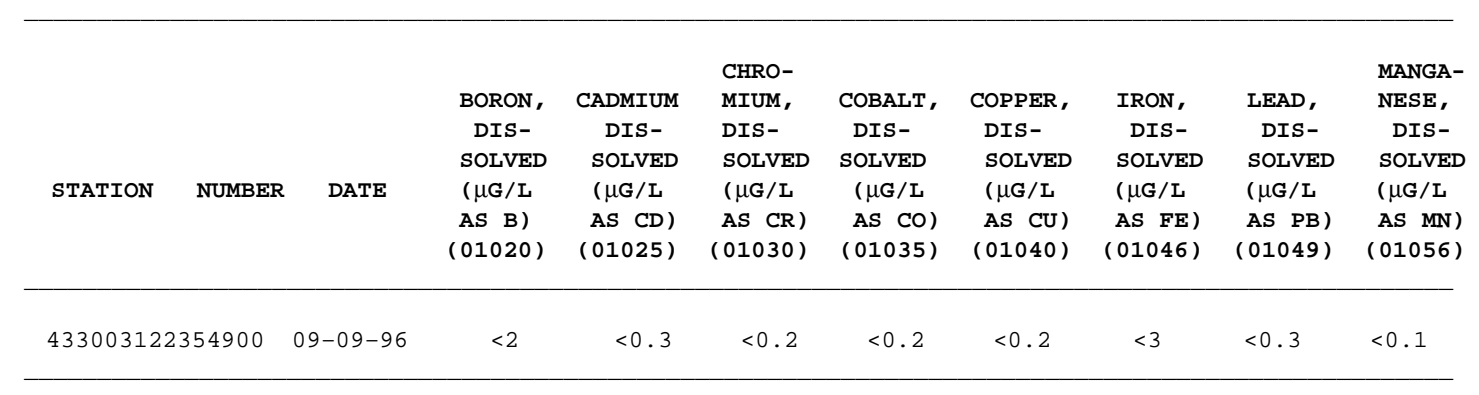

\begin{tabular}{|c|c|c|c|c|c|c|c|c|c|}
\hline STATION & DATE & $\begin{array}{c}\text { THAL- } \\
\text { LIUM, } \\
\text { DIS- } \\
\text { SOLVED } \\
(\mu G / \mathrm{L} \\
\text { AS TL) } \\
(01057)\end{array}$ & $\begin{array}{c}\text { MOLYB- } \\
\text { DENUM, } \\
\text { DIS- } \\
\text { SOLVED } \\
(\mu \mathrm{G} / \mathrm{L} \\
\text { AS MO) } \\
(01060)\end{array}$ & $\begin{array}{l}\text { NICKEL, } \\
\text { DIS- } \\
\text { SOLVED } \\
(\mu \mathrm{G} / \mathrm{L} \\
\text { AS NI) } \\
(01065)\end{array}$ & $\begin{array}{c}\text { SELE- } \\
\text { NIUM, } \\
\text { DIS- } \\
\text { SOLVED } \\
(\mu G / L \\
\text { AS SE) } \\
(01145)\end{array}$ & $\begin{array}{c}\text { SILVER, } \\
\text { DIS- } \\
\text { SOLVED } \\
(\mu G / L \\
\text { AS AG) } \\
(01075)\end{array}$ & $\begin{array}{c}\text { STRON- } \\
\text { TIUM, } \\
\text { DIS- } \\
\text { SOLVED } \\
(\mu \mathrm{G} / \mathrm{L} \\
\text { AS SR) } \\
(01080)\end{array}$ & $\begin{array}{c}\text { ZINC, } \\
\text { DIS- } \\
\text { SOLVED } \\
(\mu G / L \\
\text { AS ZN) } \\
(01090)\end{array}$ & $\begin{array}{c}\text { URANIUM } \\
\text { NATURAL } \\
\text { DIS- } \\
\text { SOLVED } \\
(\mu G / L \\
\text { AS U) } \\
(22703)\end{array}$ \\
\hline 433003122354900 & $09-09-96$ & $<0.1$ & $<0.2$ & $<0.5$ & $<1$ & $<0.2$ & $<0.1$ & 0.92 & $<0.2$ \\
\hline
\end{tabular}


APPENDIX B. CHEMICAL ANALYSIS OF THE QUALITY ASSURANCE

SAMPLES-Continued

Table B-2. Concentrations of nutrients, major ions, and trace elements in field split sample

[Dissolved, operationally defined as water that has been passed though a 0.45 micrometer filter; constituent concentrations in MG/L, milligrams per liter or $\mu \mathrm{G} / \mathrm{L}$, micrograms per liter; number in parenthesis is the U.S. Environmental Protection Agency Storage and Retrieval (STORET) database code]

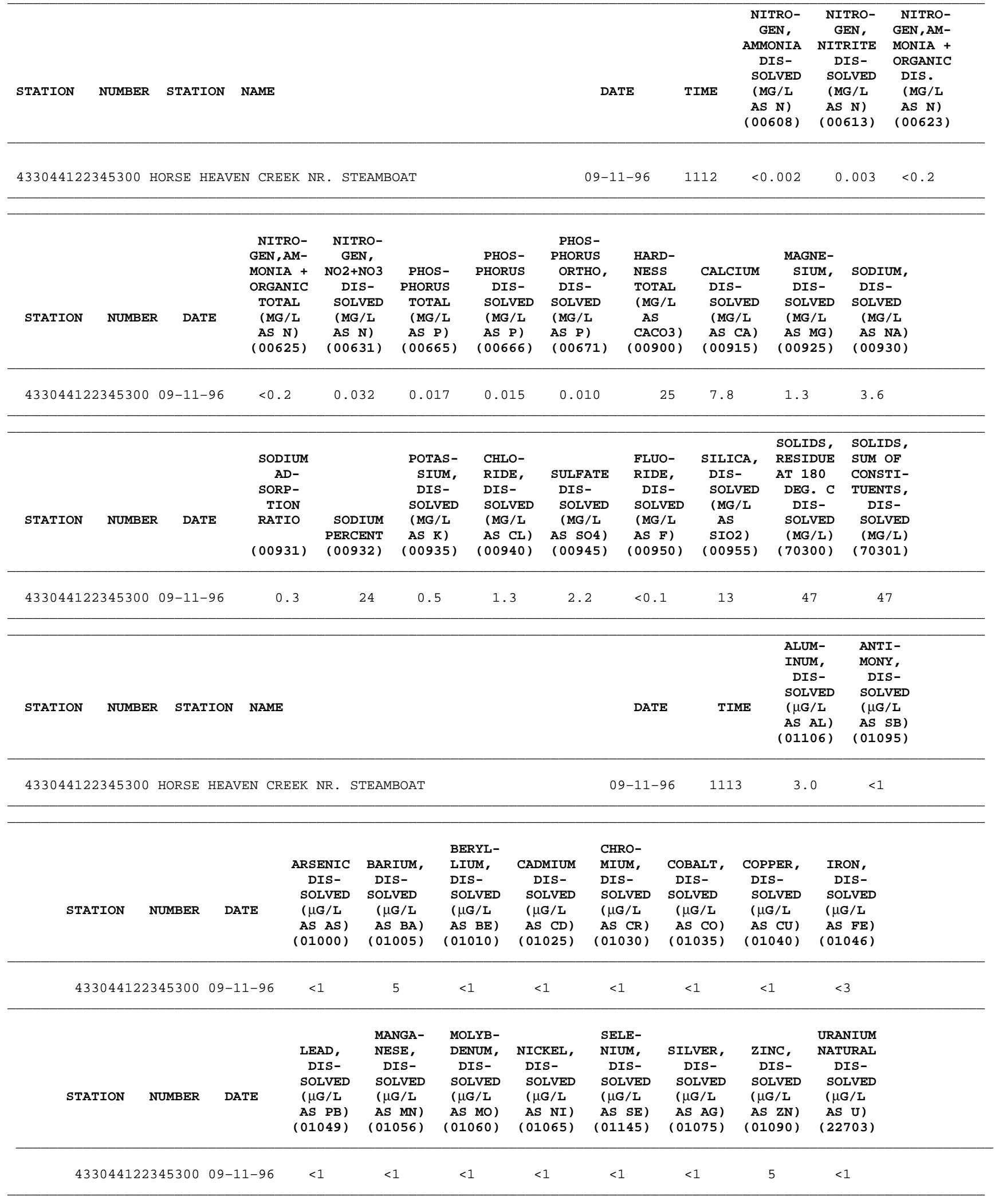


APPENDIX B. CHEMICAL ANALYSIS OF THE QUALITY ASSURANCE SAMPLES-Continued

Table B-3. Concentrations of trace elements in less than $(<) 2$ millimeter (MM) bottom sediment [Concentrations in $\mu \mathrm{G} / \mathrm{G}$ (micrograms per gram) or in PERCENT; WS, wet sieved]

\begin{tabular}{|c|c|c|c|c|c|c|c|c|c|c|c|}
\hline STATION & NUMBER & STATION & NAME & & & & & DATE & TIME & $\begin{array}{l}\text { ALUM- } \\
\text { INUM } \\
\text { <2MM WS } \\
\text { FIELD } \\
\text { PERCENT }\end{array}$ & $\begin{array}{l}\text { ANTI- } \\
\text { MONY } \\
\text { <2MM WS } \\
\text { FIELD } \\
(\mu G / G)\end{array}$ \\
\hline \multicolumn{2}{|c|}{433044122345300} & HORSE HEAVED & \multicolumn{3}{|c|}{ EN CREEK NR. STEAMBOAT } & \multicolumn{3}{|c|}{$09-11-96$} & 1112 & 7.7 & 6.0 \\
\hline STATION & NUMBER & DATE & $\begin{array}{c}\text { ARSENIC } \\
\text { <2MM WS } \\
\text { FIELD } \\
(\mu G / G)\end{array}$ & $\begin{array}{l}\text { BARIUM } \\
\text { <2MM WS } \\
\text { FIELD } \\
(\mu G / G)\end{array}$ & $\begin{array}{l}\text { BERYL- } \\
\text { LIUM } \\
\text { <2MM WS } \\
\text { FIELD } \\
(\mu G / G)\end{array}$ & $\begin{array}{c}\text { BISMUTH } \\
\text { <2MM WS } \\
\text { FIELD } \\
(\mu G / G)\end{array}$ & $\begin{array}{c}\text { CADMIUM } \\
\text { <2MM WS } \\
\text { FIELD } \\
(\mu G / G)\end{array}$ & $\begin{array}{l}\text { CALCIUM } \\
\text { <2MM WS } \\
\text { FIELD } \\
\text { PERCENT }\end{array}$ & $\begin{array}{l}\text { CERIUM } \\
\text { <2MM WS } \\
\text { FIELD } \\
(\mu G / G)\end{array}$ & $\begin{array}{l}\text { CHRO- } \\
\text { MIUM } \\
\text { <2MM WS } \\
\text { FIELD } \\
(\mu G / G)\end{array}$ & $\begin{array}{l}\text { COBALT } \\
\text { <2MM WS } \\
\text { FIELD } \\
(\mu G / G)\end{array}$ \\
\hline 433044122 & 345300 & $09-11-96$ & 24 & 410 & 1 & $<10$ & 1.2 & 2.0 & 25 & 35 & 17 \\
\hline
\end{tabular}

\begin{tabular}{|c|c|c|c|c|c|c|c|c|c|c|c|}
\hline STATION & NUMBER & DATE & $\begin{array}{l}\text { COPPER } \\
\text { <2MM WS } \\
\text { FIELD } \\
(\mu G / G)\end{array}$ & $\begin{array}{l}\text { EURO- } \\
\text { PIUM } \\
\text { <2MM WS } \\
\text { FIELD } \\
(\mu \mathrm{G} / \mathrm{G})\end{array}$ & $\begin{array}{c}\text { GALLIUM } \\
\text { <2MM WS } \\
\text { FIELD } \\
(\mu G / G)\end{array}$ & $\begin{array}{l}\text { GOLD } \\
\text { <2MM WS } \\
\text { FIELD } \\
(\mu G / G)\end{array}$ & $\begin{array}{c}\text { HOLMIUM } \\
\text { <2MM WS } \\
\text { FIELD } \\
(\mu \mathrm{G} / \mathrm{G})\end{array}$ & $\begin{array}{l}\text { IRON } \\
\text { <2MM WS } \\
\text { FIELD } \\
\text { PERCENT }\end{array}$ & $\begin{array}{c}\text { LANTHA- } \\
\text { NUM } \\
\text { <2MM WS } \\
\text { FIELD } \\
(\mu G / G)\end{array}$ & $\begin{array}{l}\text { LEAD } \\
<2 M M \text { WS } \\
\text { FIELD } \\
(\mu G / G)\end{array}$ & $\begin{array}{c}\text { LITHIUM } \\
\text { <2MM WS } \\
\text { FIELD } \\
(\mu G / G)\end{array}$ \\
\hline 433044122 & 2345300 & $09-11-96$ & 32 & $<2$ & 18 & $<8$ & $<4$ & 5.4 & 16 & 40 & 30 \\
\hline
\end{tabular}

\begin{tabular}{|c|c|c|c|c|c|c|c|c|c|c|c|}
\hline STATION & NUMBER & DATE & $\begin{array}{l}\text { MAGNE- } \\
\text { SIUM } \\
\text { <2MM WS } \\
\text { FIELD } \\
\text { PERCENT }\end{array}$ & $\begin{array}{l}\text { MANGA- } \\
\text { NESE } \\
\text { <2MM WS } \\
\text { FIELD } \\
(\mu G / G)\end{array}$ & $\begin{array}{c}\text { MERCURY } \\
\text { <2MM WS } \\
\text { FIELD } \\
(\mu G / G)\end{array}$ & $\begin{array}{l}\text { MOLYB- } \\
\text { DENUM } \\
\text { <2MM WS } \\
\text { FIELD } \\
(\mu G / G)\end{array}$ & $\begin{array}{l}\text { NEODYM- } \\
\text { IUM } \\
\text { <2MM WS } \\
\text { FIELD } \\
(\mu G / G)\end{array}$ & $\begin{array}{l}\text { NICKEL } \\
\text { <2MM WS } \\
\text { FIELD } \\
(\mu \mathrm{G} / \mathrm{G})\end{array}$ & $\begin{array}{c}\text { NIOBIUM } \\
\text { <2MM WS } \\
\text { FIELD } \\
(\mu G / G)\end{array}$ & $\begin{array}{l}\text { PHOS- } \\
\text { PHORUS } \\
<2 \text { MM WS } \\
\text { FIELD } \\
\text { PERCENT }\end{array}$ & $\begin{array}{l}\text { POTAS- } \\
\text { SIUM } \\
\text { <2MM WS } \\
\text { FIELD } \\
\text { PERCENT }\end{array}$ \\
\hline 43304412 & 345300 & $09-11-96$ & 0.97 & 1200 & 0.21 & $<2$ & 14 & 10 & 10 & 0.07 & 1.0 \\
\hline
\end{tabular}

\begin{tabular}{|c|c|c|c|c|c|c|c|c|c|c|c|}
\hline STATION & NUMBER & DATE & $\begin{array}{l}\text { SCAN- } \\
\text { DIUM } \\
\text { <2MM WS } \\
\text { FIELD } \\
(\mu G / G)\end{array}$ & $\begin{array}{l}\text { SELE- } \\
\text { NIUM } \\
\text { <2MM WS } \\
\text { FIELD } \\
(\mu G / G)\end{array}$ & $\begin{array}{l}\text { SILVER } \\
\text { <2MM WS } \\
\text { FIELD } \\
(\mu G / G)\end{array}$ & $\begin{array}{l}\text { SODIUM } \\
\text { <2MM WS } \\
\text { FIELD } \\
\text { PERCENT }\end{array}$ & $\begin{array}{l}\text { STRON- } \\
\text { TIUM } \\
\text { <2MM WS } \\
\text { FIELD } \\
(\mu G / G)\end{array}$ & $\begin{array}{l}\text { SULFUR } \\
\text { <2MM WS } \\
\text { FIELD } \\
(\mu G / G)\end{array}$ & $\begin{array}{l}\text { TANTA- } \\
\text { LUM } \\
<2 \text { MM WS } \\
\text { FIELD } \\
(\mu G / G)\end{array}$ & $\begin{array}{c}\text { THORIUM } \\
\text { <2MM WS } \\
\text { FIELD } \\
(\mu G / G)\end{array}$ & $\begin{array}{c}\text { TIN } \\
\text { <2MM WS } \\
\text { FIELD } \\
(\mu G / G)\end{array}$ \\
\hline 43304412 & 345300 & $09-11-96$ & 19 & 0.1 & 0.3 & 1.8 & 290 & $<0.05$ & $<40$ & $<3$ & $<5$ \\
\hline
\end{tabular}

\begin{tabular}{|c|c|c|c|c|c|c|c|c|c|c|c|}
\hline STATION & NUMBER & DATE & $\begin{array}{c}\text { TITA- } \\
\text { NIUM, } \\
\text { SED, BM } \\
\text { WS, <2MM } \\
\text { DRY WGT } \\
\text { REC } \\
\text { PERCENT }\end{array}$ & $\begin{array}{c}\text { URANIUM } \\
\text { BOT MAT } \\
\text { <2MM WS } \\
\text { FIELD } \\
(\mu G / G)\end{array}$ & $\begin{array}{l}\text { VANA- } \\
\text { DIUM } \\
\text { BOT MAT } \\
\text { <2MM WS } \\
\text { FIELD } \\
(\mu G / G)\end{array}$ & $\begin{array}{c}\text { YTTRIUM } \\
\text { BOT MAT } \\
\text { <2MM WS } \\
\text { FIELD } \\
(\mu G / G)\end{array}$ & $\begin{array}{l}\text { YTTER- } \\
\text { BIUM } \\
\text { BOT MAT } \\
\text { <2MM WS } \\
\text { FIELD } \\
(\mu G / G)\end{array}$ & $\begin{array}{l}\text { ZINC } \\
\text { BOT MAT } \\
\text { <2MM WS } \\
\text { FIELD } \\
(\mu G / G)\end{array}$ & $\begin{array}{c}\text { CARBON, } \\
\text { ORGANIC } \\
\text { SED, BM } \\
\text { WS, <2MM } \\
\text { DW, REC } \\
\text { (PER- } \\
\text { CENT) }\end{array}$ & $\begin{array}{c}\text { CARBON, } \\
\text { INORG, } \\
\text { SED, BM } \\
\text { WS, <2MM } \\
\text { DW, REC } \\
\text { (PER- } \\
\text { CENT) }\end{array}$ & $\begin{array}{c}\text { CARBON, } \\
\text { ORG + } \\
\text { INORG, } \\
\text { SED, BM } \\
\text { WS, <2MM } \\
\text { DW, REC } \\
\text { PERCENT }\end{array}$ \\
\hline 433044122 & 2345300 & $09-11-96$ & 0.580 & 1.7 & 130 & 24 & 2 & 290 & 0.31 & 0.01 & 0.32 \\
\hline
\end{tabular}


Page Intentionally Blank 
APPENDIX C 
Page Intentionally Blank 


\section{APPENDIX C. CHEMICAL ANALYSIS OF THE ENVIRONMENTAL SAMPLES}

Table C-1. Field measurements, and concentrations of nutrients and major ions in unfiltered and filtered water samples collected from the Steamboat Creek Basin, 1996

[DEG C, degrees Celsius; MM OF HG, millimeters of mercury; $\mu \mathrm{S} / \mathrm{CM}$ microSiemens per centimeter at 25 degrees Celsius; MG/L, milligrams per liter; CO3, carbonate; $\mathrm{HCO} 3$, bicarbonate; $\mathrm{CACO} 3$, calcium carbonate; dissolved, operationally defined as water which has passed through a 0.45 micrometer filter; number in parenthesis is the U.S. Environmental Protections Agency Storage and Retrieval (STORET) database code]

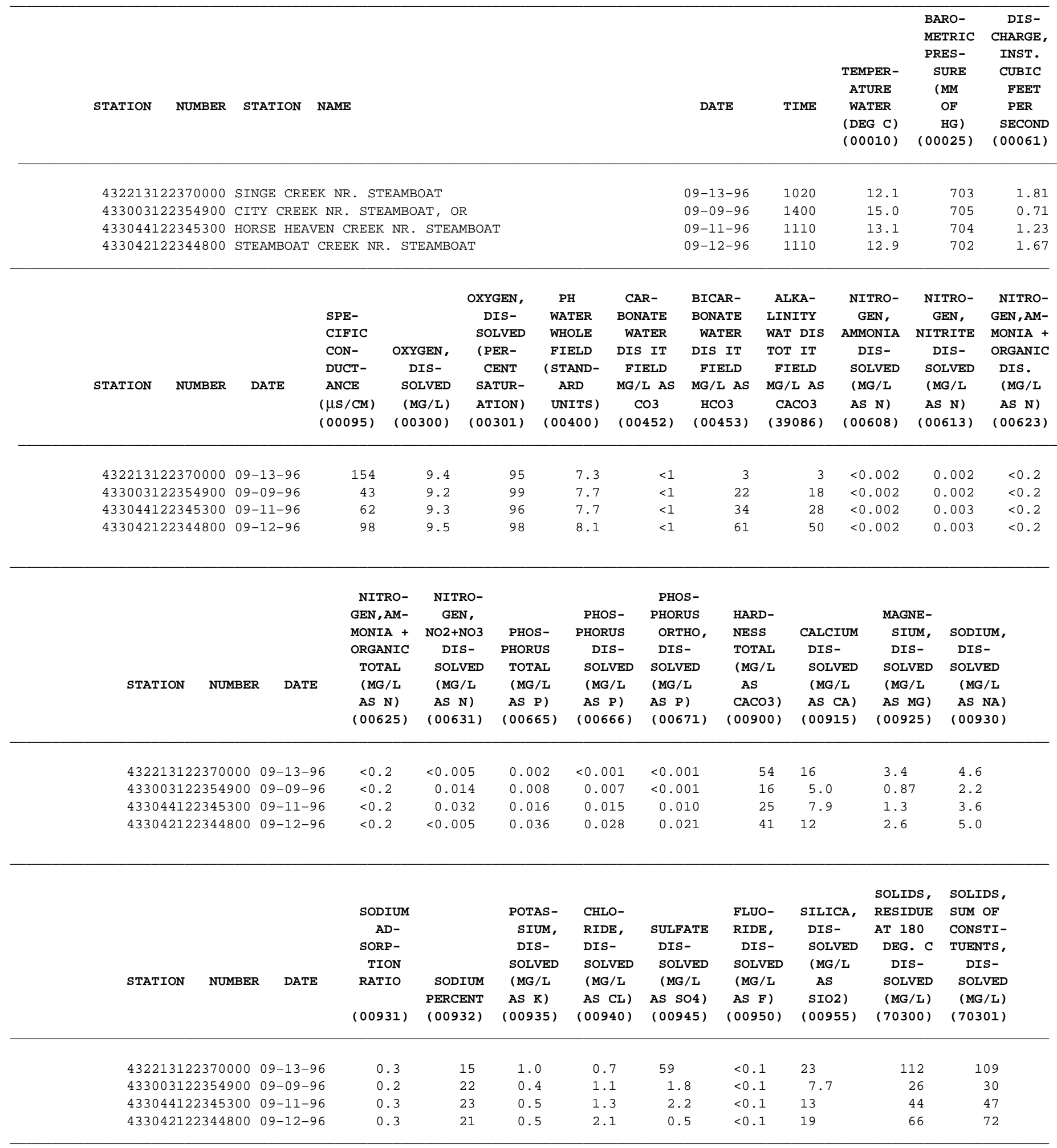




\section{APPENDIX C. CHEMICAL ANALYSIS OF THE ENVIRONMENTAL SAMPLES—Continued}

Table C-2. Concentrations of trace elements in filtered water samples collected from the Steamboat Creek Basin, 1996 [DISSOLVED, operationally defined as water that has passed through a 0.45 micrometer filter; $\mu \mathrm{G} / \mathrm{L}$, micrograms per liter; number in parenthesis is the U.S. Environmental Protection Agency Storage and Retrieval (STORET) database code]

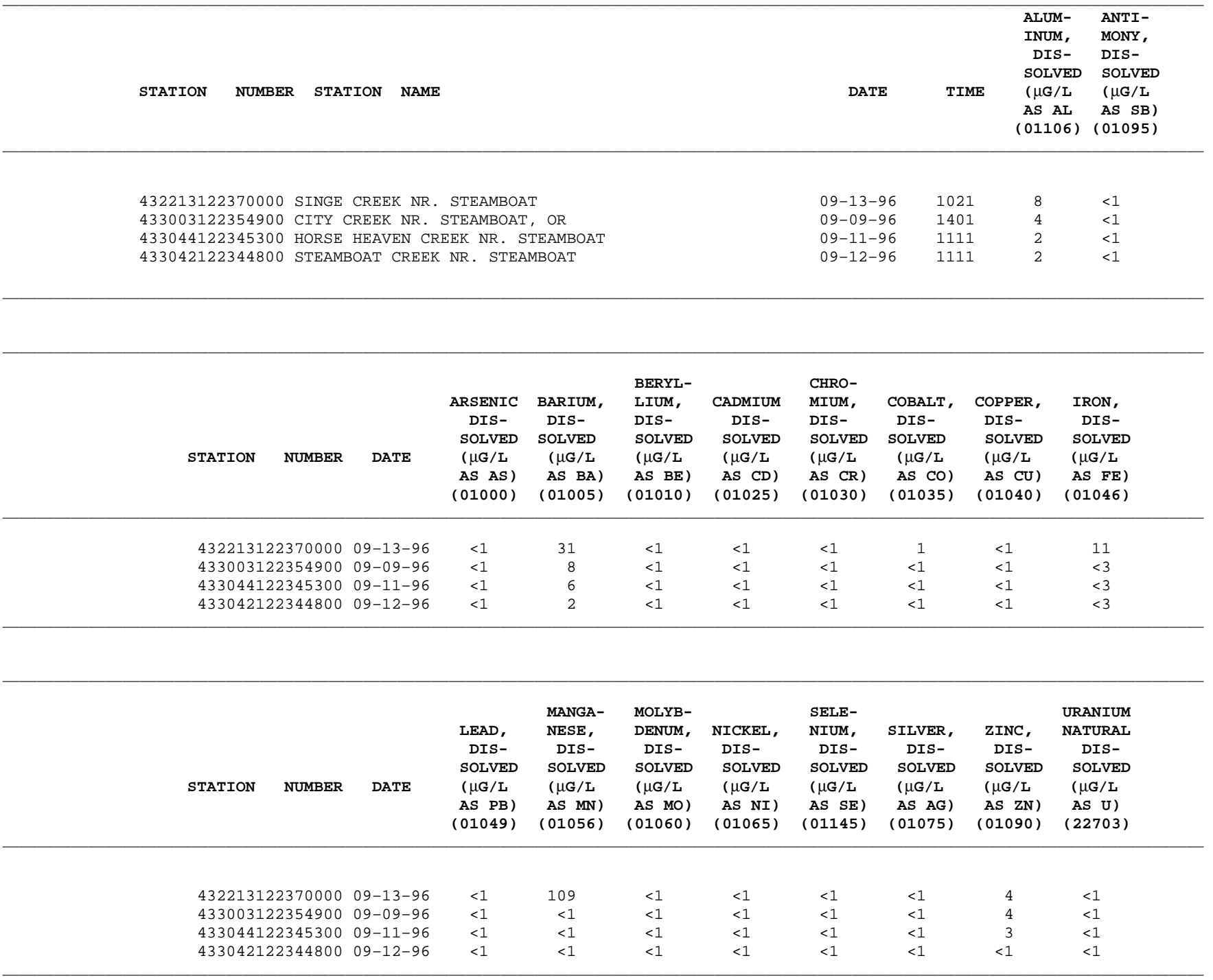




\section{APPENDIX C. CHEMICAL ANALYSIS OF THE ENVIRONMENTAL SAMPLES-Continued}

Table C-3. Concentrations of trace elements in less than $(<) 63$ micrometer bottom sediment from the Steamboat Creek Basin, 1996

[Concentrations in $\mu \mathrm{G} / \mathrm{G}$, micrograms per gram or in PERCENT; WS, wet sieved; number in parenthesis is the U.S. Environmental Protection Agency Storage and Retrieval (STORET) database code]

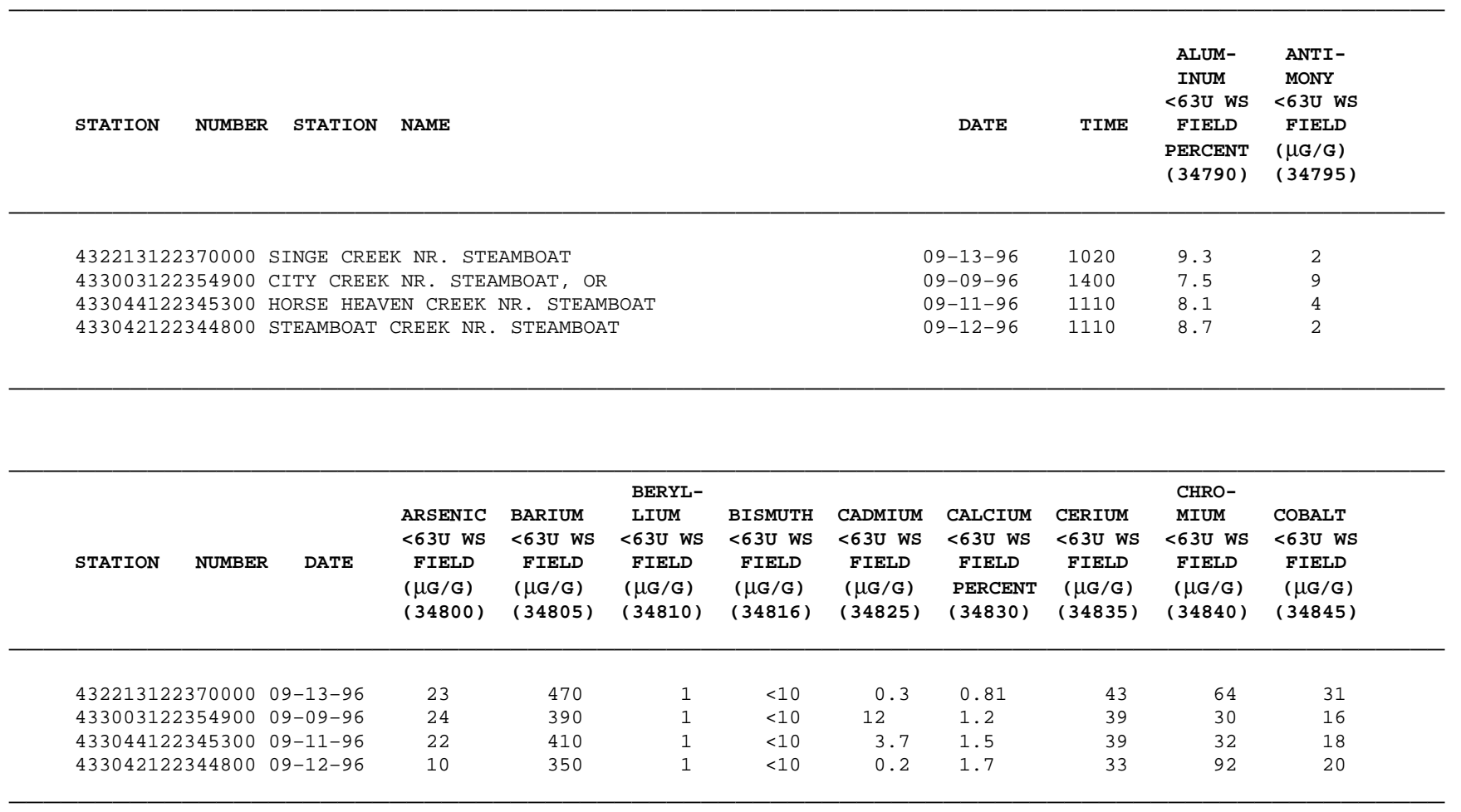

\begin{tabular}{|c|c|c|c|c|c|c|c|c|c|c|c|}
\hline STATION & NUMBER & DATE & $\begin{array}{c}\text { COPPER } \\
<63 U \text { WS } \\
\text { FIELD } \\
(\mu G / G) \\
(34850)\end{array}$ & $\begin{array}{l}\text { EURO- } \\
\text { PIUM } \\
\text { <63U WS } \\
\text { FIELD } \\
(\mu G / G) \\
(34855)\end{array}$ & $\begin{array}{c}\text { GALLIUM } \\
<63 U \text { WS } \\
\text { FIELD } \\
(\mu G / G) \\
(34860)\end{array}$ & $\begin{array}{l}\text { GOLD } \\
<63 U \text { WS } \\
\text { FIELD } \\
(\mu G / G) \\
(34870)\end{array}$ & $\begin{array}{c}\text { HOLMIUM } \\
<63 U \text { WS } \\
\text { FIELD } \\
(\mu G / G) \\
(34875)\end{array}$ & $\begin{array}{l}\text { IRON } \\
<63 \text { WS } \\
\text { FIELD } \\
\text { PERCENT } \\
(34880)\end{array}$ & $\begin{array}{c}\text { LANTHA- } \\
\text { NUM } \\
<63 U \text { WS } \\
\text { FIELD } \\
(\mu G / G) \\
(34885)\end{array}$ & $\begin{array}{l}\text { LEAD } \\
<63 U \text { WS } \\
\text { FIELD } \\
(\mu G / G) \\
(34890)\end{array}$ & $\begin{array}{c}\text { LITHIUM } \\
\text { <63U WS } \\
\text { FIELD } \\
(\mu G / G) \\
(34895)\end{array}$ \\
\hline 432213122 & 370000 & $09-13-96$ & 37 & $<2$ & 18 & $<8$ & $<4$ & 4.9 & 25 & 19 & 30 \\
\hline 433003122 & 354900 & $09-09-96$ & 86 & $<2$ & 17 & $<8$ & $<4$ & 5.0 & 25 & 240 & 40 \\
\hline 433044122 & 345300 & $09-11-96$ & 58 & $<2$ & 20 & $<8$ & $<4$ & 5.6 & 24 & 44 & 40 \\
\hline 433042122 & 344800 & $09-12-96$ & 25 & $<2$ & 21 & $<8$ & $<4$ & 5.8 & 20 & 14 & 40 \\
\hline
\end{tabular}

\begin{tabular}{|c|c|c|c|c|c|c|c|c|c|c|c|}
\hline STATION & NUMBER & DATE & $\begin{array}{l}\text { MAGNE- } \\
\text { SIUM } \\
\text { <63U WS } \\
\text { FIELD } \\
\text { PERCENT } \\
(34900)\end{array}$ & $\begin{array}{l}\text { MANGA- } \\
\text { NESE } \\
<63 U \text { WS } \\
\text { FIELD } \\
(\mu G / G) \\
(34905)\end{array}$ & $\begin{array}{c}\text { MERCURY } \\
<63 U \text { WS } \\
\text { FIELD } \\
(\mu G / G) \\
(34910)\end{array}$ & $\begin{array}{l}\text { MOLYB- } \\
\text { DENUM } \\
<63 U \text { WS } \\
\text { FIELD } \\
(\mu G / G) \\
(34915)\end{array}$ & $\begin{array}{c}\text { NEODYM- } \\
\text { IUM } \\
<63 U \text { WS } \\
\text { FIELD } \\
(\mu G / G) \\
(34920)\end{array}$ & $\begin{array}{l}\text { NICKEL } \\
<63 U \text { WS } \\
\text { FIELD } \\
(\mu G / G) \\
(34925)\end{array}$ & $\begin{array}{c}\text { NIOBIUM } \\
<63 U \text { WS } \\
\text { FIELD } \\
(\mu G / G) \\
(34930)\end{array}$ & $\begin{array}{l}\text { PHOS- } \\
\text { PHORUS } \\
<63 U \text { WS } \\
\text { FIELD } \\
\text { PERCENT } \\
(34935)\end{array}$ & $\begin{array}{l}\text { POTAS- } \\
\text { SIUM } \\
\text { <63U WS } \\
\text { FIELD } \\
\text { PERCENT } \\
(34940)\end{array}$ \\
\hline 432213122 & 370000 & $09-13-96$ & 0.78 & 900 & 0.14 & $<2$ & 24 & 24 & 9 & 0.08 & 1.1 \\
\hline 433003122 & 354900 & 09-09-96 & 0.74 & 1200 & 0.67 & $<2$ & 29 & 11 & 10 & 0.15 & 0.81 \\
\hline 433044122 & 345300 & $09-11-96$ & 0.91 & 1500 & 0.43 & $<2$ & 27 & 10 & 11 & 0.11 & 0.81 \\
\hline 433042122 & 344800 & $09-12-96$ & 1.3 & 990 & 0.06 & $<2$ & 22 & 33 & 12 & 0.07 & 0.63 \\
\hline
\end{tabular}




\section{APPENDIX C. CHEMICAL ANALYSIS OF THE ENVIRONMENTAL SAMPLES-Continued}

Table C-3. Concentrations of trace elements in less than $(<) 63$ micrometer bottom sediment from the Steamboat Creek Basin, 1996-Continued

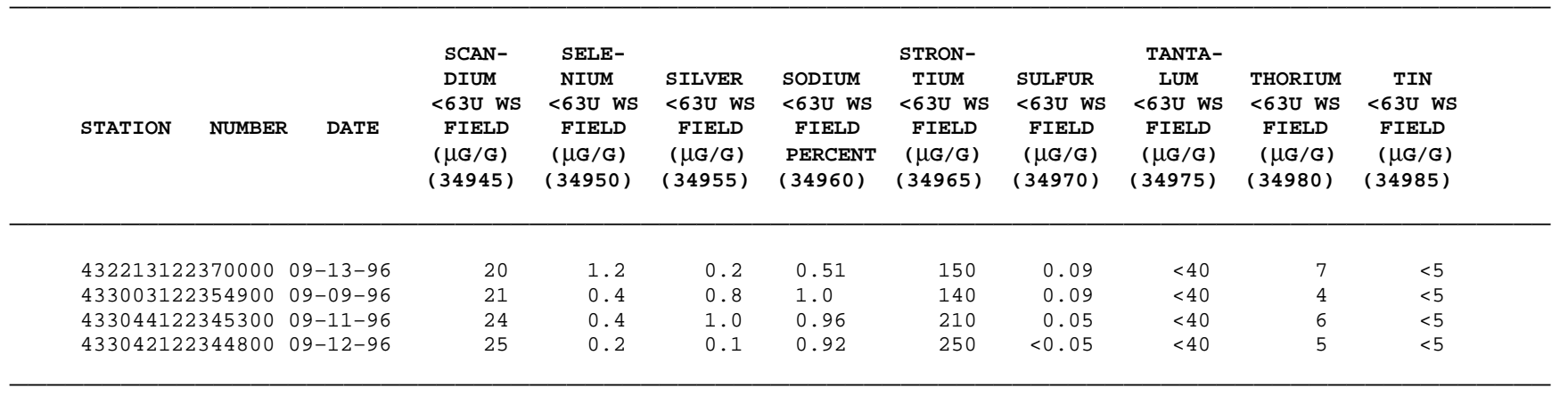

\begin{tabular}{|c|c|c|c|c|c|c|c|c|c|c|c|}
\hline STATION & NUMBER & DATE & $\begin{array}{c}\text { TITA- } \\
\text { NIUM, } \\
\text { <63U WS } \\
\text { FIELD } \\
\text { PERCENT } \\
(49274)\end{array}$ & $\begin{array}{l}\text { URANIUM } \\
<63 \text { WS } \\
\text { FIELD } \\
(\mu G / G) \\
(35000)\end{array}$ & $\begin{array}{l}\text { VANA- } \\
\text { DIUM } \\
\text { <63U WS } \\
\text { FIELD } \\
(\mu G / G) \\
(35005)\end{array}$ & $\begin{array}{c}\text { YTTRIUM } \\
<63 U \text { WS } \\
\text { FIELD } \\
(\mu G / G) \\
(35010)\end{array}$ & $\begin{array}{l}\text { YTTER- } \\
\text { BIUM } \\
\text { <63U WS } \\
\text { FIELD } \\
(\mu G / G) \\
(35015)\end{array}$ & $\begin{array}{l}\text { ZINC } \\
<63 U \text { WS } \\
\text { FIELD } \\
(\mu G / G) \\
(35020)\end{array}$ & $\begin{array}{l}\text { CARBON } \\
\text { ORGANIC } \\
<63 \text { WS } \\
\text { (PER- } \\
\text { CENT) } \\
(49266)\end{array}$ & $\begin{array}{c}\text { CARBON, } \\
\text { CARBON, } \\
\text { INORG, } \\
\text { <63U WS } \\
\text { (PER- } \\
\text { CENT) } \\
(49269)\end{array}$ & $\begin{array}{c}\text { ORG + } \\
\text { INORG, } \\
<63 \text { WS } \\
\text { (PER- } \\
\text { CENT) } \\
(49267)\end{array}$ \\
\hline 432213122 & 370000 & $09-13-96$ & 0.500 & 3.0 & 160 & 24 & 2 & 110 & 1.98 & 0.02 & 2.00 \\
\hline 433003122 & 354900 & $09-09-96$ & 0.470 & 1.6 & 120 & 33 & 2 & 690 & 6.75 & 0.03 & 6.78 \\
\hline 433044122 & 345300 & $09-11-96$ & 0.680 & 1.7 & 130 & 37 & 3 & 430 & 3.93 & 0.02 & 3.95 \\
\hline 433042122 & 344800 & $09-12-96$ & 0.760 & 1.4 & 140 & 35 & 3 & 95 & 3.12 & 0.02 & 3.14 \\
\hline
\end{tabular}


APPENDIX D 
Page Intentionally Blank 


\section{APPENDIX D. EXPLANATION OF CALCULATIONS FOR DETERMINING BREAK-POINT CONCENTRATIONS FOR CONSTITUENTS IN WILLAMETTE RIVER BASIN BOTTOM SEDIMENT}

The technique used to distinguish whether constituent concentrations in bottom sediment from four sites in the Steamboat Creek Subbasin were at background or enriched levels (naturally or because of human activities) was derived from previous work in the Willamette River Basin by Rickert and others (1977). For this report, the work done by Rickert and others was updated using bottom-sediment data collected in the Willamette River Basin from 1992-95 as part of three studies: (1) a cooperative study with the Oregon Department of Environmental Quality in the Willamette River Basin, (2) a cooperative study with the Unified Sewerage Agency of Washington County in the Tualatin River Basin, and (3) a U.S. Geological Survey National Water-Quality Assessment Program in the Willamette Basin. In these studies, bottom-sediment samples were collected from 52 sites and processed using methods outlined by Shelton and Capel (1994), and analyzed according to methods described by Arbogast (1990). Normal-probability plots showing constituent concentrations were constructed using the compiled data. If the concentrations derived for a particular constituent were from natural weathering of chemically related rock types, the concentrations would be expected to form one statistical population, represented by a straight line, on a normal-probability plot. If part of the constituent's population was derived either from human-derived sources or from unique geologic sources (for example, enrichment from cinnabar deposits), a second statistical population, as represented by a second straight line, might occur on the same normal-probability plot. A break in the two lines would then be observed between the background concentrations (the lower line) and the enriched concentrations (the upper line); the point where the two lines meet (intersect) on the plot is known as the break-point concentration. For example, the break-point concentration for silver in bottom-sediment collected in the Willamette River Basin during 1992-95 was determined to be $0.3 \mu \mathrm{g} / \mathrm{g}$ (micrograms per gram) (fig. D-1). Rickert and others (1977) showed that constituent concentrations at or below the break-point concentrations were similar to concentrations measured in uncontaminated soils in the Willamette River Basin.

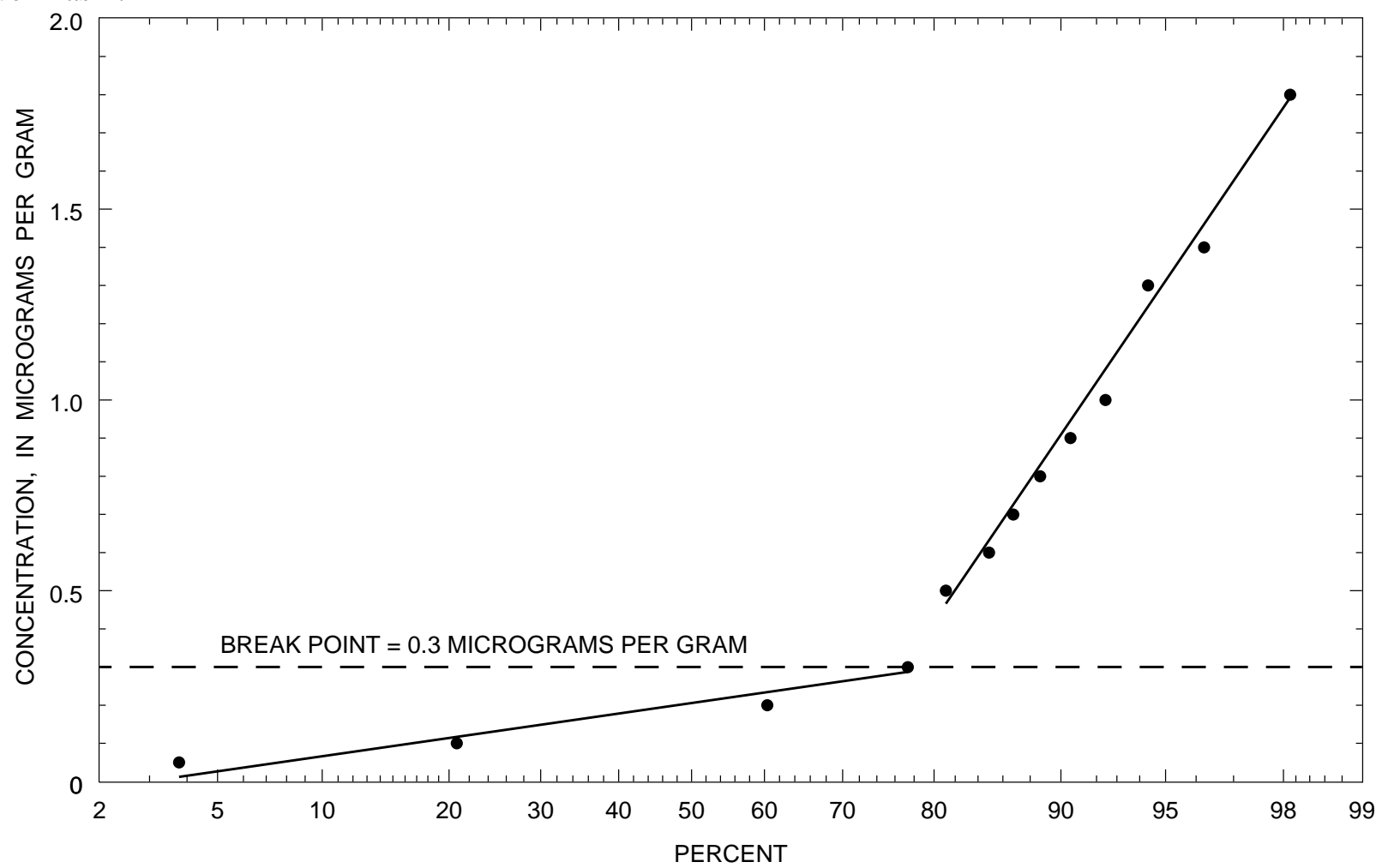

Figure D-1. Normal-probability plot of silver concentrations in less than 62 micrometer-size bottom sediment from the Willamette River Basin, Oregon, 1992-95. 
Page Intentionally Blank 